AQUATIC FLOW CYTOMETRY: ACHIEVEMENTS AND PROSPECTS. M. RECKERMANN and F. COLIJN (eds.)

\title{
Using flow cytometry for counting natural planktonic bacteria and understanding the structure of planktonic bacterial communities*
}

\author{
JOSEP M. GASOL ${ }^{1}$ and PAUL A. DEL GIORGIO² \\ ${ }^{1}$ Departament de Biologia Marina i Oceanografia, Institut de Ciències del Mar, CSIC. Passeig Joan de Borbó s/n. \\ E08039 Barcelona, Catalunya. Spain. Phone: (3493) 2216416, Fax: (3493) 2217340. E-mail: pepgasol@icm.csic.es \\ ${ }^{2}$ Horn Point Laboratory. University of Maryland Center for Environmental Science PO. Box 775 \\ Cambridge, MD 21613 USA
}

\begin{abstract}
SUMMARY: Flow cytometry is rapidly becoming a routine methodology in aquatic microbial ecology. The combination of simple to use bench-top flow cytometers and highly fluorescent nucleic acid stains allows fast and easy determination of microbe abundance in the plankton of lakes and oceans. The different dyes and protocols used to stain and count planktonic bacteria as well as the equipment in use are reviewed, with special attention to some of the problems encountered in daily routine practice such as fixation, staining and absolute counting. One of the main advantages of flow cytometry over epifluorescence microscopy is the ability to obtain cell-specific measurements in large numbers of cells with limited effort. We discuss how this characteristic has been used for differentiating photosynthetic from non-photosynthetic prokaryotes, for measuring bacterial cell size and nucleic acid content, and for estimating the relative activity and physiological state of each cell. We also describe how some of the flow cytometrically obtained data can be used to characterize the role of microbes on carbon cycling in the aquatic environment and we prospect the likely avenues of progress in the study of planktonic prokaryotes through the use of flow cytometry.
\end{abstract}

Key words: heterotrophic and phototrophic bacteria, flow cytometry, counting bacteria, active bacteria.

\section{INTRODUCTION}

Bacteria are important components of planktonic food webs: autotrophic bacteria can dominate the primary producers' compartment in oligotrophic waters (Li et al., 1992; Campbell et al., 1994; Buck et al., 1996) and contribute a large percentage to total primary production (Li, 1994; Vaulot et al., 1995). Chemoheterotrophic bacteria participate with an important share of total plankton biomass (Gasol

\footnotetext{
*Received May 10, 1999. Accepted February 7, 2000.
}

et al., 1997) that at times can be higher than, or at least similar to, that of primary producers (Li et al., 1992, Fuhrman et al., 1989; Simon et al., 1992). Bacterial contribution to planktonic heterotrophic activity is known to be very large (Azam and Hodson, 1977), and bacterial production has been estimated to be in the order of $30 \%$ of primary production (Cole et al., 1988; Ducklow and Carlson, 1992). Altogether, bacterial activity can have a large impact on ecosystem metabolism either in the ecosystem balance between production and respiration (del Giorgio et al., 1997a), the turnover of organic car- 
bon and the global carbon cycle (Cho and Azam, 1988), or the back- and forward transformations between POC and DOC (Azam, 1998).

Bacterial abundance and biomass are thus key parameters in aquatic ecosystems, and constitute the most essential measurements made in virtually all studies of planktonic systems. Until recently, most determinations of bacterial biomass were done via a two-step process in which abundance is first determined, usually by epifluorescence microscopy of DAPI- or Acridine Orange-stained samples (e.g. Kepner and Pratt, 1994) and later bacterial biomass is derived from measurements of cell size, usually with image-analysis (e.g. Blackburn et al., 1998). The whole procedure may easily take many personhours per sample analyzed, thus making real-time analysis of microbial abundance impossible at a rate commensurate with the acquisition of physical measurements of the water masses (Yentsch et al., 1983). The traditional microscopic techniques do not lend themselves to large-scale studies, such as oceanographic cruises, which easily generate thousands of samples for which we would like to have bacterial abundance and biomass estimates.

Microbial ecologists also seek to measure properties other than density and size of bacterioplankton, such as the composition and relative activity of individual cells and their phylogenetic affiliation. Incubations with radioactive tracers (i.e. Kirchman, 1993) or microscopic assessment using a variety of cellular probes (Sherr et al., 1999) are the means employed to obtain estimates of relative activity. These procedures are even more time-consuming and force a sampling frequency further away from the ideal. Thus, all of the methods that offer information on the heterogeneity of the bacterial community (i.e. different sizes, different cell-specific activities, etc.) are very time-consuming, lack resolution and often lack precision because a relatively modest number of cells can be examined. There is now a new generation of methods, including flow cytometry, that are significantly reducing the time employed in each of these determinations, increasing the level of resolution and in addition, providing new insights into the structure and functioning of plankton communities that simply can not be obtained with conventional epifluorescence microscopy.

The suite of techniques based on the analysis of microscope images has been labeled Image Cytometry in opposition to Flow Cytometry (FC). FC allows the examination of a large number of cells at a time, recording for each cell several different parameters that can later be linked to a wide variety of cellular characteristics (Shapiro, 1995). In a flow cytometer, typically on the order of 200 to over 2000 cells per second circulate through the beam of a laser or an arc-lamp, and the electronic circuitry captures the light scattered by each of the particles and the fluorescence emission at different wavelengths generated by the excitation of each particle. This multivariate information is then processed and combined as desired by a computer. Because tens of thousands of cells can be analyzed in a few minutes, and as long as the system is able to operate with particles in the bacterial size range, FC can really reduce the time needed for the determination of bacterial abundance, size and activity, offering simultaneous information on the structure (heterogeneity) of the bacterial assemblage with a large statistical significance. While the cytometer is based on the measure of scattered light, it is the additional capability of resolving natural or induced particle-associated fluorescence that makes the technique particularly useful. Fluorescent DNA stains, activity probes, nucleic acid probes and immunofluorescence probes extend the capabilities of the technique making it able to discriminate cells on the basis of amount and type of nucleic acids, amount of respiratory enzymes, or many other characteristics. In this respect, a FC is conceptually an image cytometry system that can operate at great speed and that can be almost fully automated (e.g. Jacquet et al., 1998a).

The application of flow cytometry to aquatic microbial ecology has been slow relative to other fields. The basic elements of flow cytometry were developed over three decades ago (Shapiro, 1995), and a variety of commercial and in house instruments have been available since then and used in many clinical and research applications. But until recently, flow cytometers remained very expensive and out of the reach of most ecological laboratories, and until a few years ago they needed the work of a dedicated technician which made operating costs even higher. Furthermore, commercial flow cytometers were designed for the analysis of cells that are larger than bacteria (namely blood cells). Extension of their operation to microbiological research was possible but not without difficulties. This was particularly true for natural aquatic bacteria, which are extremely small, have relatively low amounts of cell constituents, and external cell structures that might hamper or obstruct the access of fluorochromes, 
antibodies or nucleic acid probes to the cells. Thus, the statement by Jernaes and Steen (1994): "Flow cytometry of bacteria is still in its infancy". There has been much progress since this statement was made, to the point that we can now state that the enumeration and analysis of natural planktonic bacteria by flow cytometry is routine in many laboratories and is becoming an essential technique in aquatic microbial ecology studies. The current explosion in the use of FC in ecological studies has been in part fueled by the availability of new nuclear acid stains together with powerful, sensitive and relatively cheap benchtop flow cytometers. Few areas of research or few techniques have had such an amount of review papers and books in relatively few years: Darzynkiewicz and Crissman (1990), Ormerod (1994), Lloyd (1993), Fouchet et al. (1993), Troussellier et al. (1993), Methods in Cell Biology (1994), Shapiro (1995), Davey and Kell (1996), Porter et al. (1997), Davey et al. (1999), Collier and Campbell (1999), etc. However, and with the exception of the Trousellier et al. (1993) paper, and small sections in the complete reviews of Davey and Kell (1996) and Collier and Campbell (1999), little has been published on the application of flow cytometry to natural planktonic bacteria, an area that has flourished after the papers of Li et al. (1995), del Giorgio et al. (1996) and Marie et al. (1997) that independently realized the potential of the blue-light excitable stains marketed by Molecular Probes.

This paper will not review extensively the methods associated with flow cytometry of bacteria nor will it focus on the work that has been done to date with bacterial cultures in the laboratory. Instead, we intend to provide an introduction to researchers interested in the routine estimation of bacterial abundance, biomass and activity in natural planktonic ecosystems. Some revision of the work done with bacterial cultures is unavoidable as most of the work carried out in ecosystems starts with work at the culture level, but we will try to focus on the applications to natural planktonic bacteria.

\section{BACTERIA AND FLOW CYTOMETRY}

Bacteria are small, and planktonic bacteria are usually much smaller than their laboratory relatives. This has been the main limitation preventing the development of applications using flow cytometry to their study. As cultured bacteria $\left(>2 \mu \mathrm{m}^{3}\right.$ cell $\left.^{-1}\right)$ are many times larger than planktonic or soil bacte- ria (typically $<0.2 \mu \mathrm{m}^{3}$ cell $^{-1}$, and often $<0.06 \mu \mathrm{m}^{3}$ cell $^{-1}$ ), analyses involving bacterial cultures were possible well before any attempts of studying natural populations of bacteria. As early as 1977 flow cytometry was used to study bacterial cultures (Bailey et al., 1977, Paau et al., 1977). Somehow surprisingly, what researchers were worried about 20 years ago was quite similar to the problems we are interested with natural bacteria today: determination of DNA (Paau et al., 1977) and protein (Hutter and Eipel, 1978), differentiation of "live" and "dead" cells (Hutter and Eipel, 1978) and separation of microorganisms on the basis of DNA content and the presence of chlorophyll (Paau et al., 1979). The first studies applying flow cytometry to bacteria dealt with the description of the macromolecular composition of bacterial cells during the growth cycle: changes in DNA were found to correlate with the fluorescence of the probes used (see below), changes in protein content with changes in bacterial size (Allman et al., 1990) and changes in the scatter of light by the cells have been found to reflect changes in bacterial size (Allman et al., 1990) or the accumulation of reserve polymers such as poly- $\beta$ hydroxybutirate (e.g. Srienc et al., 1984).

The ability to characterize the macromolecular changes during bacterial growth has been applied to monitoring the effects of antibiotics on bacteria (e.g. Crissman et al., 1978; Steen et al., 1982, 1986) and other stress-producing substances (e.g. Comas and Vives-Rego, 1997), and characterizing the starvation-survival response of selected bacterial species, usually those with pathogenic relevance (Thorsen et al., 1992; Lebaron and Joux, 1994). The development of fluorescent probes that indicate various aspects of cell metabolism has further stimulated this area of research (McFeters et al., 1995; Porter et al., 1996; Davey et al., 1999).

Most of the early FC work was done with arclamp cytofluorometers, and even today these are more sensitive for the analysis of small particles than the commercial flow cytometers (e.g. Bernarder et al., 1998). The arc-lamp cytometer is an instrument in which a flat, laminar stream of water, containing the stained cells in a narrow central sector, is formed on a microscope cover slip by a pressurized jet of water directed onto the glass at a low angle. The stream of cells is viewed by means of a fluorescence microscope with incident illumination and one or several photomultipliers (Steen and Lindmo, 1979). These instruments were commercialized under different brand names (Skatron 
Argus-100, BioRad Bryte and Bruker ACR 1400$\mathrm{Sp}$ ), and were for a while a cheap and practical alternative to the laser-based flow cytometers. These instruments had the added advantage of combining UV excitation in a small machine, since UV lasers required a high power source and thus, expensive and sophisticated refrigeration systems. At a time when blue-excitable stains for DNA quantification were almost non existent, this was a powerful reason to purchase an arc-lamp cytometer to study bacteria. Another advantage of these instruments was the possibility of easily changing excitation wavelengths (Peters, 1979).

Some of the properties of the molecules used to stain the cells, which often were antibiotic molecules that affected the structure of the DNA, were used to characterize bacterial species. Van Dilla et al. (1983), for example, used a combination of a GC-specific stain (chromomycin A) and an AT specific stain (Hoechst 33258), in combination with light scatter, to differentiate mixed bacterial cultures and determine their base-pair content. Other approaches to detecting specific microorganisms in water, food or in body fluids were developed combining several of the variables provided by the cytometers: light scatter (as surrogates of size and internal structure), protein and DNA content (Ingram et al., 1982; Miller and Quarles, 1990; Allman et al., 1992) or by the use of fluorescently labeled specific antibodies (Tyndall et al., 1985) or genetic probes (Amann et al., 1990).

Most of the early published studies focused on the detection of a defined bacterial species either in culture, or in the environment (released, surviving, or in full growth). It was not until the early 90's that researchers started to use FC to examine and enumerate all bacterial cells in mixed natural assemblages (e.g. Pinder et al., 1990).

\section{Bacterial detection by light scattering}

Detection of natural planktonic bacteria can not usually be accomplished only on the basis of their light scattering properties, in part because bacterial sizes are in the range of the wavelengths used to "see" them. In addition, natural water samples usually have large numbers of detrital submicrometric particles and colloids that scatter light similarly to live bacteria. Light scattering is used in conjunction with fluorescence to discriminate bacteria, and in itself may provide important information about the cells. The amount of bacterial scattered light is a complex function of cell size, internal structure, particle orientation, refractive indexes of the particle and of the medium, etc. Cellular inclusions like PHB (Srienc et al., 1984), sulfur (E.O.Casamayor and J.M.Gasol, unpubl. obs.), proteins (Wittrup et al., 1988), magnetosomes (Wallner et al., 1997) and cyanobacterial vacuoles (Dubelaar et al., 1987) change the amount of scattered light without associated changes in cell size. To make things more difficult, fixation and dye annexation can also change the scatter properties of the cells (see below). Some authors have relied on scattered light to discriminate among bacterial isolates (e.g. Allman et al., 1993) but most often this has been achieved in combination with some type of nucleic acid staining (Allman et al., 1992). Photosynthetic bacteria of sizes $<1 \mu \mathrm{m}$ $\left(0.2-0.6 \mu \mathrm{m}^{3}\right)$ are easily discriminated on the basis of light scattered and chlorophyll content (Chisholm et al., 1988; Cristina X.P., pers. com.) producing usually a quite sharp peak in the light scatter channels despite their small size.

As a general rule, small angle $\left(2-15^{\circ}\right)$ light scattering (FSC or FALS) has been found to be related to cell mass or cell volume while wide angle (15$90^{\circ}$ ) light scattering (SSC or WALS) is related to the refractive index of the cellular content (e.g. Wittrup et al., 1988). Forward scatter might work well at differentiating organisms larger than bacteria (algae and heterotrophic protists). However, differences exist between machine types (i.e. the arc-lamp based machines are better than most laser flow cytometers, Bernander et al., 1998) and even between the newest machines (i.e. Coulter XL and FACSCalibur, Jiménez-Gómez F., pers. com.).

\section{Bacterial detection after staining}

Because light scattering does not in itself allow discrimination of bacterial cells from other particles, it is necessary to use fluorescence in addition to light scatter to detect cells. Researchers have turned to fluorescent products that are excitable by blue and UV radiation of the argon lasers and mercury lamps and make bacteria fluoresce with an intensity that can be recorded with the aid of photomultipliers (Haugland, 1999). With a strong enough binding of stain to the cellular product, and large molar extinction coefficients, these stains have fostered the expansion of flow cytometry of bacteria.

The ideal fluorochrome to stain bacteria for FC detection should have an excitation maximum in the regions of the spectrum that match the emission of 
available lasers and lamps, should have a high quantum yield (the amount of photons produced per photon absorbed), should be specific for the target compound, its binding characteristics and affinities should be well known, should be soluble in water, should easily penetrate cells, and should not be toxic if cell sorting is desired. However, no single fluorochrome that is currently available fulfills all these requisites. The choice of stains is constrained because most flow cytometers either have argon lasers which emit in the blue ( $488 \mathrm{~nm}$, usually at low powers, i.e. $15 \mathrm{~mW}$ ), or UV lasers (usually at high powers, i.e. $5 \mathrm{~W}$ ), although red excitation is also a possibility in some instruments. Most of the fluorochromes available are membrane impermeant, which requires a step of fixation and/or permeabilization (see below), and although the mechanism of staining of some of the stains in vitro is known, experiments with bacteria, specially those living in the plankton, suggest that the behavior of the stains is quite different in vivo (e.g. Guindulain et al., 1997; Lebaron et al., 1998).
The stains that have most frequently been used to view bacteria by flow cytometry are listed in Table 1. They are mostly specific for nucleic acids, with a few noteworthy exceptions: FITC and SYPRO (see spelling of the abbreviations in Table 1) stain proteins. FITC was used as a protein stain since the beginning of flow cytometry of bacteria (Bailey et al., 1977), but its use is problematic in plankton samples, where there may be many protein-rich particles in the bacterial size range (Long and Azam, 1996). BVC-kanamycin stains all cellular surfaces, and has the interesting property of emitting in the far red, which allows combination to green dyes (Depierreux et al., 1990).

Those stains that bind to DNA and RNA either intercalate into the double-stranded helical structure $(\mathrm{EthBr}, \mathrm{PI})$, with a considerable increase in fluorescence emission over that of the free dye, or are nonintercalating and fit specific regions of the DNA (like DAPI and HOECHST). Depending on their molecular size and ionic characteristics, some of these stains are cell-permeant and can

TABLE 1. - Some characteristics of the stains that have been employed to detect bacteria with flow cytometry (dye characteristics adapted from Haugland 1996 and Davey and Kell 1996).

\begin{tabular}{|c|c|c|c|c|}
\hline Stain & Binds to: & Exc. / Em. (nm) & Type of sample & References \\
\hline Ethidium bromide (EthBr) & DNA and RNA & $518 / 605$ & cultures & Paau et al. 1977, Pinder et al. 1990 \\
\hline Propidium iodide $(\mathrm{PI})$ & DNA and RNA & $535 / 617$ & cultures & $\begin{array}{l}\text { Bailey et al. 1977, Hutter and Eipel 1979, } \\
\text { Miller and Quarles } 1990\end{array}$ \\
\hline $\begin{array}{l}\text { Fluorescein isothiocyanate } \\
\text { (FITC) }\end{array}$ & protein & $495 / 520$ & $\begin{array}{l}\text { cooling towers } \\
\text { cultures }\end{array}$ & $\begin{array}{l}\text { Tyndall et al. } 1985 \\
\text { Bailey et al. } 1977, \text { Miller and Quarles 1990, } \\
\text { Allman et al. } 1990\end{array}$ \\
\hline Chromomycin A3 & DNA (GC) & $340 / 470$ & cultures & Boye et al. 1983, van Dilla et al. 1983 \\
\hline Acridine orange (AO) & $\mathrm{RNA}^{*}$ & $460 / 650^{*}$ & $\begin{array}{l}\text { cultures } \\
\text { seawater }\end{array}$ & $\begin{array}{l}\text { Nishimura et al. } 1995 \\
\text { Nishimura et al. } 1995\end{array}$ \\
\hline Mithramycin and EthBr & DNA and RNA & $425 / 550$ & cultures & $\begin{array}{l}\text { Boye et al. } 1983 \text {, Thorsen et al. } 1992, \\
\text { Allman et al. } 1992, \text { Steen } \text { et al. } 1994\end{array}$ \\
\hline DAPI & DNA & $358 / 461$ & cultures & van Dilla et al. 1983 \\
\hline HOECHST 33342 & DNA (AT) & $350 / 461$ & $\begin{array}{l}\text { marine and freshwater } \\
\text { cultures } \\
\text { marine }\end{array}$ & $\begin{array}{l}\text { Robertson and Button } 1989 \\
\text { van Dilla et al. } 1983 \\
\text { Monger and Landry } 1993\end{array}$ \\
\hline $\begin{array}{l}\text { Benzoxazinone-kanamycin } \\
\text { (BVC kanamycin) }\end{array}$ & cell surfaces & $495 / 616$ & cultures & Depierreux et al. 1990 \\
\hline TO-PRO-1 & DNA and RNA** & $515 / 531$ & marine & Li et al. 1995 \\
\hline TOTO-1 & DNA and RNA** & $514 / 533$ & marine & Li et al. 1995, Zubkov et al. 1998 \\
\hline SYTO-13 & DNA and RNA** & $488 / 514$ & $\begin{array}{l}\text { freshwater } \\
\text { marine }\end{array}$ & $\begin{array}{l}\text { del Giorgio et al. } 1996 \\
\text { Guindulain et al. } 1997 \text {, Lebaron et al. } 1998\end{array}$ \\
\hline YOYO-1 & DNA and RNA & $491 / 509$ & cultures & Marie et al. 1996 \\
\hline YO-PRO-1 & DNA and RNA & $491 / 509$ & cultures & Marie et al. 1996 \\
\hline PicoGreen & dsDNA & $480 / 520$ & $\begin{array}{l}\text { cultures } \\
\text { marine }\end{array}$ & $\begin{array}{l}\text { Marie et al. } 1996, \text { Veldhuis et al. } 1997 \\
\text { Sieracki } \text { et al. } 1999\end{array}$ \\
\hline SYBRGreen I & DNA and RNA & 494 / 521 & $\begin{array}{l}\text { marine } \\
\text { freshwater }\end{array}$ & $\begin{array}{l}\text { Marie et al. } 1997 \\
\text { Lebaron } \text { et al. } 1998\end{array}$ \\
\hline SYTOX & dsDNA & $504 / 523$ & cultures & Veldhuis et al. 1997 \\
\hline SYTO-9, 11, BC & DNA (and RNA) & $480-510 / 500-520$ & freshwater and marine & Lebaron et al. 1998 \\
\hline SYBRGreen II & RNA (and DNA) & $492 / 521$ & freshwater and marine & Lebaron et al. 1998 \\
\hline SYTO-17 & DNA and RNA & $633 / 675$ & cultures & Comas and Vives-Rego 1997 \\
\hline SYTO-16 & DNA and RNA & $488 / 518$ & cultures & Ibrahim et al. 1997 \\
\hline SYPRO & Protein & $550 / 630$ & cultures & Zubkov et al. 1999 \\
\hline
\end{tabular}

* AO also stains DNA with excitation / emission maxima at 500 and $526 \mathrm{~nm}$

** Only DNA in plankton samples (see Li et al. 1995 and Guindulain et al. 1997) 
easily cross bacterial membranes, or are essentially imperment to live or intact membranes. In some cases, the stain can cross the cellular membrane but is then actively pumped out from the live cell. DAPI, one of the most commonly used stains for bacteria enumeration on filters by epifluorescence (Kepner and Pratt, 1994), tends to bind nonspecifically to cell membranes (Coleman et al., 1981; Zweifel and Hagström, 1995) and it is likely that most other nucleic acid stains do so in some degree. Most of the stains have selective binding to DNA and to RNA, with different fluorescence yields, at least in vitro. However, even those that are marketed as preferentially staining RNA tend to also stain DNA (see the comparison of SybrGreen I and II in Lebaron et al., 1998). Acridine orange is an intercalating dye that emits orange/red fluorescence when interacting with single-stranded nucleic acids, and fluoresces green when interacting with double-stranded nucleic acids. Even though this characteristic has been used to measure RNA in bacterial samples (Nishimura et al., 1995), the stain is very sensitive to the conditions of use, and tends to bind nonspecifically (Petit et al., 1993). Some of the DNA stains have shown differential binding to AT (DAPI, HOECHST) or to GC (chromomycin, mithramycin and olivomycin) base pairs, and combination of both types of dyes has been used to measure the \%GC content of bacterial cultures and as an additional characteristic for classification (van Dilla et al., 1983). The company Molecular Probes started a few years ago to market families of nucleic-acid cyanide dyes with a range of excitation maxima, including many that could be excited with the blue light of the Argon laser that most commercial flow cytometers have. They marketed the TOTO and the TO-PRO series, which are cell-impermeant; the SYTO series, with lower affinity for nucleic acids, but cell-permeant and useful for work with live cells; the SybrGreen series, with very high affinities for RNA and DNA; the SYTOX green stain which is also cell impermeant and is marketed as an exclusion stain; and others such as the PicoGreen, also with high affinity for DNA. A whole variety of these products, with different yields and different excitation and emission wavelengths is available (Haugland, 1999) and some of them have successfully been used to stain bacteria (Table 1). In fact, Molecular Probes is marketing a SYTO Bacterial counting kit to be used with flow cytometry.

\section{Detection of planktonic bacteria}

Tyndall et al. (1985) were probably the first authors to detect the presence of indigenous bacteria using FC, although they were probing for the presence of Legionella with FITC-labeled antibodies and propidium iodide. Robertson and Button (1989) reported the use of a more sensitive cytometer in combination with DAPI staining as a means of observing seawater and freshwater planktonic bacteria. They were among the first to report that these natural bacteria were equally stained when treated with RNAse (indicating that the stain was attached mostly to DNA), that two subpopulations were at times visible, and that they could differentiate cells according to their chlorophyll content, as the red fluorescence of the chlorophyll appeared in a very different channel than the DAPI blue fluorescence. Similar work, with similar flow cytometers was produced by Monfort and Baleux (1992), Troussellier et al. (1993) and Heldal et al. (1994), with slight modifications of the Robertson and Button protocol.

Monger and Landry (1993) introduced HOECHST 33342 as a DNA stain because this was superior to DAPI in terms of lower background fluorescence, smaller coefficients of variation of blue fluorescence and better accuracy of abundance estimates. The relative fluorescence quantum yield (relative to unbound dye in solution) is $30 \%$ higher for HOECHST than for DAPI and staining was done in less time. Monger and Landry also noticed that UV excitation was not effective to discriminate Prochlorococcus in oligotrophic oceanic waters where these organisms make an important contribution to picoplankton abundance, and they suggested the use of double excitation (UV excitation of HOECHST-stained DNA and blue excitation of the chlorophyll). These authors again noted the presence of different planktonic bacterial subpopulations based on light scattering and fluorescence characteristics. Work with this setup allowed Campbell et al. (1994) to estimate the (large) contribution of prochlorophytes to planktonic community structure in oligotrophic oceans.

Until 1995, however, most DNA stains available required UV excitation and thus high-powered lasers, with sophisticated alignment systems and large refrigeration units, prone to technical problems. These cytometers were expensive, required maintenance, and the dedicated work of a technician. Li et al. (1995) and del Giorgio et al. (1996) introduced blue-excitable stains for enumerating plankton bacteria. Li et al. 


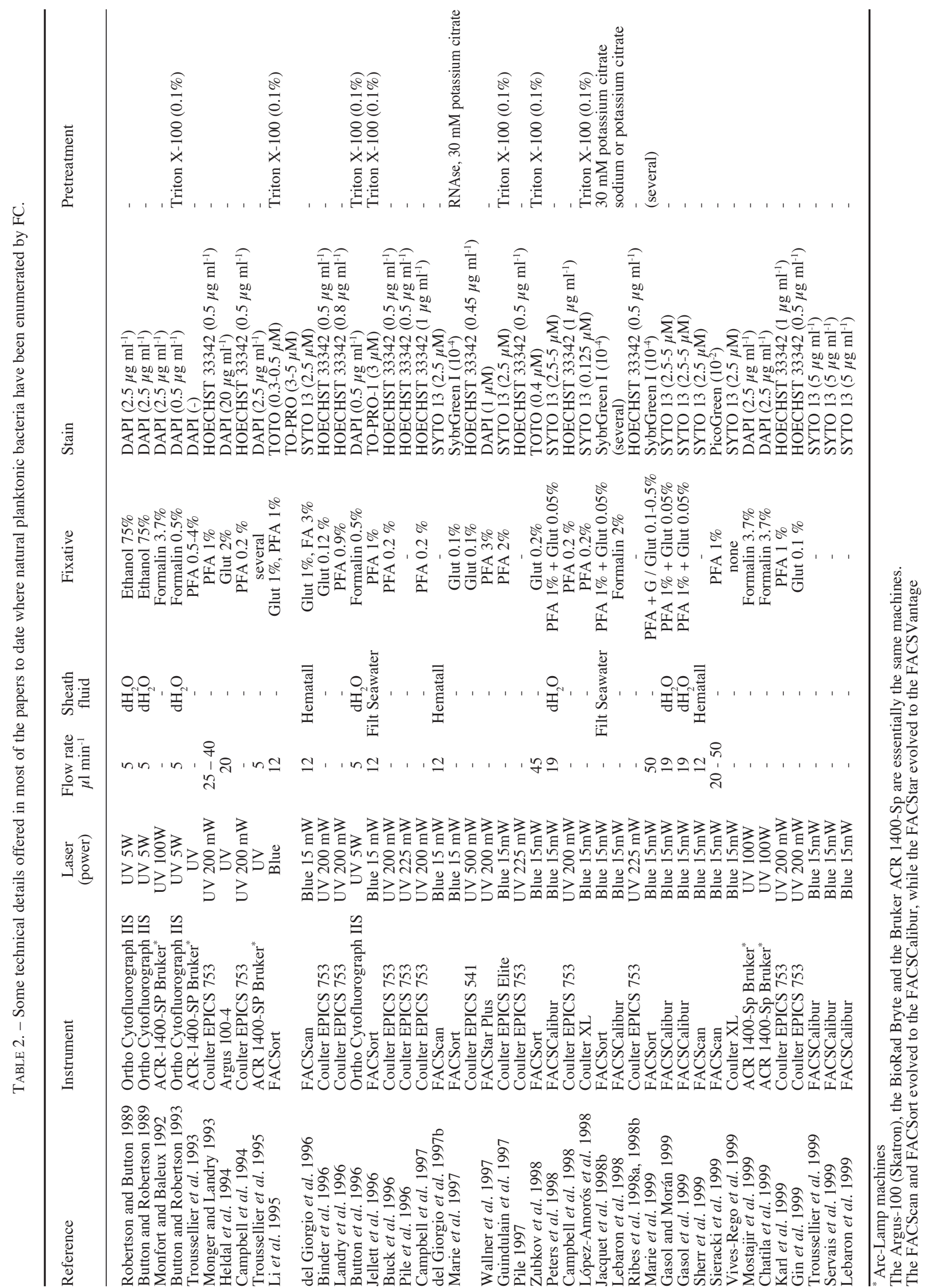


(1995) showed that TOTO-1 and TO-PRO-1 stained preferentially DNA, that they could differentiate two or three bacterial subpopulations, and that these subpopulations appeared to have ecological meaning. del Giorgio et al. (1996) and Guindulain et al. (1997) introduced the use of SYTO-13, and Marie et al. (1997) compared another blue-green stain, SybrGreen favorably to HOECHST 33342 for counting planktonic bacteria. These authors also noticed that the phototrophic prokaryotes Prochlorococcus and Synechococcus could be discriminated from chemotrophic bacteria in a plot of red vs. green fluorescence, except where the phototrophs' autofluorescence was very weak, as in the surface well-stratified oceanic waters, Olson et al., 1990). SybrGreen I has also been successfully used to enumerate planktonic viruses (Marie et al., 1999) and flagellates (authors' unpublished results). Sieracki et al. (1999), Veldhuis (pers. com.) and Gregori and Denis (pers. com.) are more comfortable using PicoGreen for staining bacteria in marine samples. This stain has been used to estimate the amount of DNA in planktonic phototrophs and also
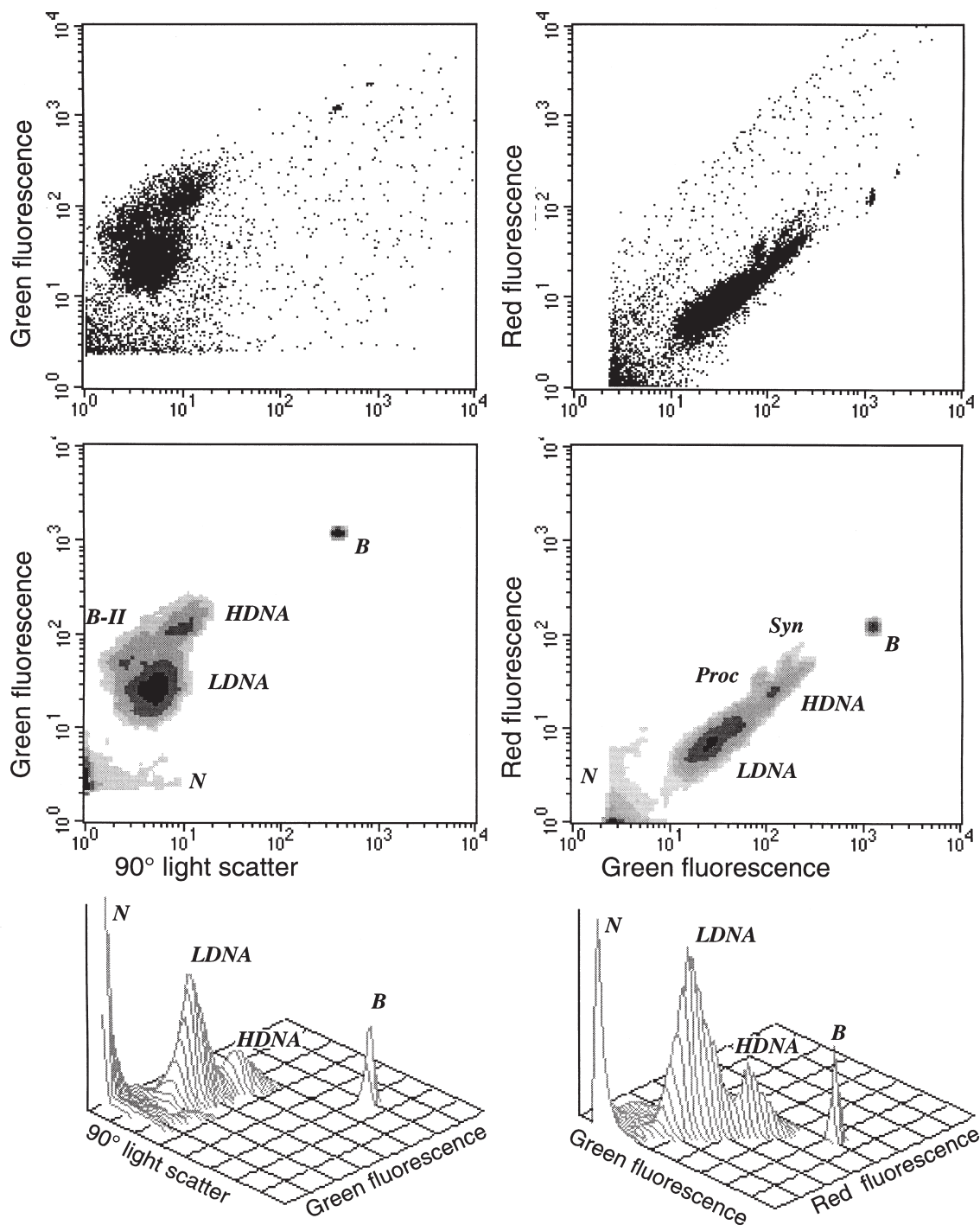

FIG. 1. - Flow cytometric analysis of a surface open Atlantic ocean sample after staining with SYTO 13. In the upper panels, 10000 events are displayed after acquisition in log mode. In the left side of the graph, a representation of $90^{\circ}$ light scatter (SSC or WALS) vs. green fluorescence (FL1 in our instrument). In the right side, a representation of green fluorescence vs. red fluorescence (FL3 in our instrument). In this specific acquisition, no electronic compensation was applied to the fluorescences, and slightly more voltage was applied to the FL3 photomultipliers than to the FL1 photomultipliers. Central panels: A log-density plot of the same data presented in the upper panels. One step of data smoothing was applied, and a threshold of $1 \%$ eliminated isolated data. Denser gray levels identify logarithmically increasing quantities of events. Interpretation of the different subpopulations that appear is as follow: B: Yellow-green $1 \mu \mathrm{m}$ Polysciences latex beads. N: electronic noise. HDNA: Bacteria with High DNA content (also known as Li et al.'s Group II bacteria, and Marie et al.'s B-III bacteria). LDNA: Bacteria with Low DNA content (also known as Li et al.'s Group I bacteria, and Marie et al.'s B-I bacteria). Syn: Synechococcus. Proc: Prochlorococcus. B-II: Group II bacteria according to Marie et al. (1997). Lower panels: a three-dimensional representation of the same data after 1 smoothing step and removal of $1 \%$ of data. Same symbols identify the same populations. 
stains bacteria well (Veldhuis et al., 1997). Lebaron et al. (1998) compared most of the above-cited stains and others from the Molecular Probes catalog to find out that most were similarly adequate for staining freshwater and marine planktonic bacteria, although SYTO 9 appeared to perform best in terms of mean cell fluorescence. At this time it seems that the most widely used stains are SYTO 13, SybrGreen I, and PicoGreen, but the reasons for the choice are mainly of personal habit. Table 2 summarizes the different protocols reported in the literature used to determine the abundance of planktonic bacteria with FC. Note the exponentially increasing number of papers using the technique, and the general switch from UV to blue light lasers after 1995.

Figure 1 presents an example of a Mediterranean surface water sample as it appears when stained with SYTO 13. The central and lower panels of this figure help understanding of the raw data presented in the upper panels. The threshold to trigger an event is set in green fluorescence, and that determines the vertical line below which no events appear. The plots of green fluorescence vs. side scatter, orange vs. green fluorescence and red vs. green fluorescence are helpful in discriminating subpopulations. In this example there are at least five subpopulations of bacteria that can be differentiated on the basis of autofluorescence, SYTO staining and light scatter: two of phototrophic and three of chemotrophic prokaryotes. In the following sections we discuss the meaning of the different subpopulations.

Button and Robertson (1993) have emphasized some of the advantages of analyzing bacteria with flow cytometry: large sample size that allows robust statistics; speed, accuracy and reproducibility; minimal interference by noise; resolution of specific subpopulations on the basis of size and DNA contents, estimation of genome size and sorting capabilities. To these, some others should be added: the procedure is fast $(\sim 1$ minute per sample, 100 samples can be processed -data analysis included- in a morning's work), allows counting in very small volumes (down to $1 \mu \mathrm{l}$, Troussellier et al., 1993), allows physiological probing simultaneously to enumeration (e.g. López-Amorós et al. 1998), and sample processing can be automated (e.g. Jacquet et al., 1998a). We have further determined that counting bacteria by FC in our laboratories saves $~ 50 \%$ of the cost of epifluorescence analysis (including consumables and personnel, but not including machine purchase and maintenance). The unwanted consequence is that, being easier and faster, we are now taking more samples for bacterial counts ! COUNTING BACTERIOPLANKTON, IN PRACTICE

In this section we will explore practical aspects of the flow cytometric enumeration of bacteria, focusing on three key steps of the protocol: Cell fixation, cell staining and data processing and interpretation. In Table 2 we have summarized the different protocols currently used by researchers, to highlight the diversity of approaches that have been taken.

\section{Fixation}

Fixation of samples is needed whenever the samples cannot be processed fresh immediately after sampling. But fixation may in addition be required to permeabilize cells and thus facilitate the penetration of certain stains into the cell (Bullock, 1984). The ideal fixation protocol should be fast, should effectively preserve nucleic acids, and protect autofluorescence without altering the size and the light scatter properties of the cells. Fixatives currently used include ethanol (70\%), formaldehyde, diluted as formalin or methanol-free as paraformaldehyde (PFA), glutaraldehyde (Glut) and even TCA (Rice $e t$ al., 1997) and cold shock followed by metabolic inhibition (to block stain efflux pumps, Wallberg et al., 1998). Paraformaldehyde (the solid form of formaldehyde, as opposite to the commonly used hydrolysed form, which is $40 \%$ formaldehyde and has methanol) quickly penetrates the cells and is assumed to be the most effective fixative of nucleic acids and proteins. Glutaraldehyde penetrates slowly and may not permeate all gram negative bacteria (Bullock, 1984). However, 1\% Glut was found to protect microbes from cell lysis and loss of autofluorescence upon rapid freezing in liquid nitrogen and long-term cryogenic storage (Vaulot et al., 1989). $1 \%$ PFA has been seen to offer similar protection (Monger and Landry, 1993) and fluorescence protection was even better when the samples were frozen after fixation (Hall, 1991; Zubkov et al., 1999). Campbell et al. (1994), however, did not find any differences between fixation with PFA and with Glut. Glutaraldehyde, unless of very good quality, may produce an autofluorescence signal in FC that can be very annoying (Booth, 1987). And formalin is known to negatively affect cell fluorescence (Crissman et al., 1978; Lebaron et al., 1998; Troussellier et al., 1999).

Some degree of post-fixation cell disappearance 


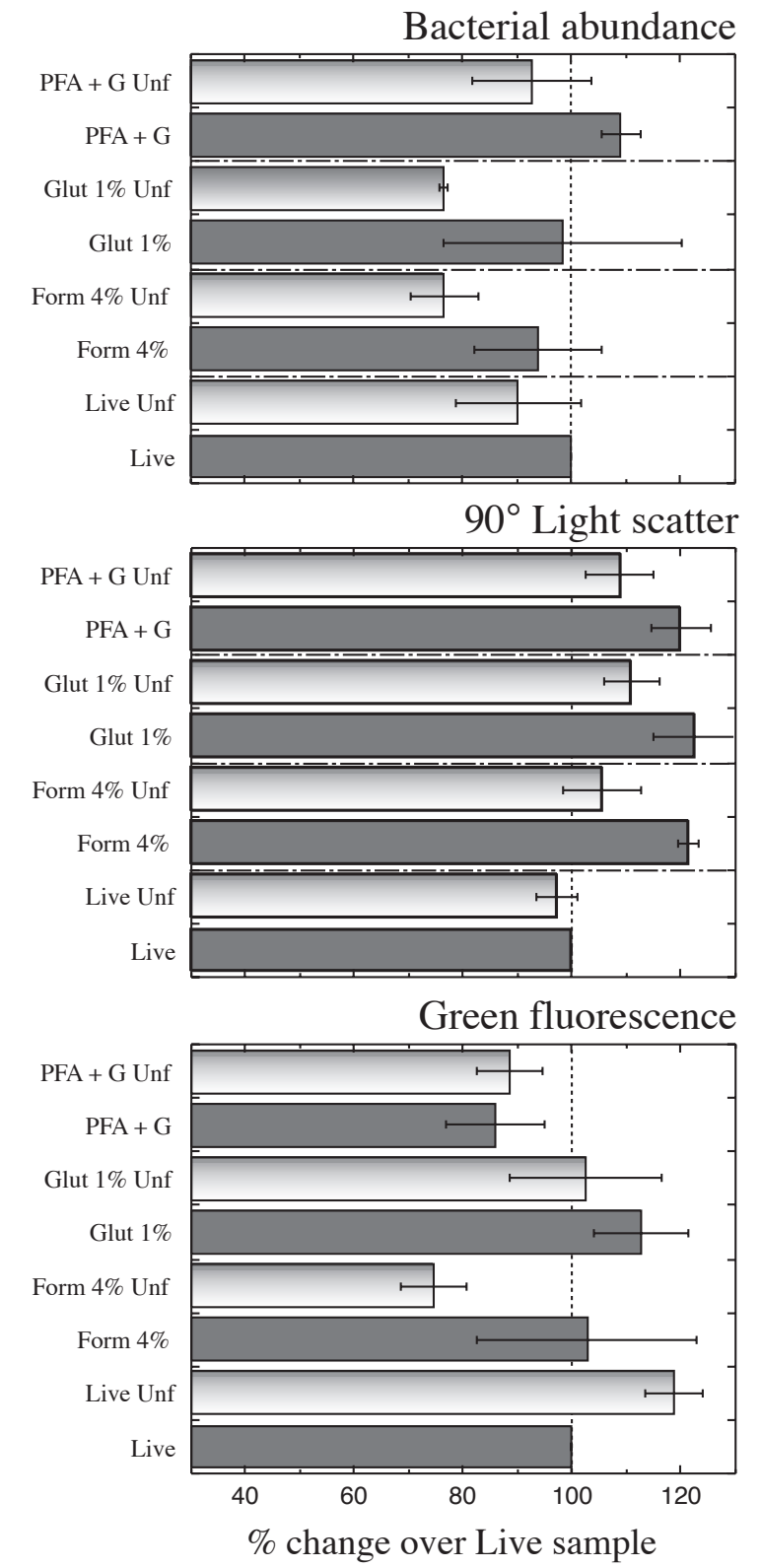

FIG. 2. - Effect of some fixation protocols on bacterial abundance, bacterial side scatter and bacterial green fluorescence after staining with SYTO 13. The values are expressed as percentage of the "live" treatment (unfixed and unfrozen). Average plus standard error (or range) of two samples: a coastal Mediterranean one, and an agedwater open Mediterranean sample. Treatments are: No fixation ("live"), $4 \%$ formalin, $1 \%$ glutaraldehyde and $1 \%$ Paraformaldehyde plus $0.01 \%$ glutaraldehyde. UNF: indicates that after fixation the sample was frozen in liquid nitrogen, left for a few minutes and later unfrozen to run the analyses.

and cell alteration has been reported with most common fixatives. Marie et al. (1993) reported that $0.5 \%$ PFA produced a 9\% loss of Prochlorophyte cells, and Troussellier et al (1995) reported a similar value. del Giorgio et al. (1996) found that fixation with formalin and glutaraldehyde decreased the forward scatter and green fluorescence and increased side scatter of fixed cells relative to live cells. They assigned those changes to post-fixation cell shrinkage that seemed to be particularly important in the case of formalin.

We tested some of these fixatives in two marine samples, with or without, freezing in liquid nitrogen (Fig. 2). The protocol labeled PFA $+\mathrm{G}$ consists in PFA $1 \%+0.05 \%$ Glut (Marie et al., 1996). The two samples, one from an oligotrophic site and the other from eutrophic waters, responded differently to some of the treatments. There was some degree of cell loss even in the fixed and frozen samples, but loss was greater for formalin and Glut treatments. Side scatter increased in all treatments, especially if no freezing was involved. A $10 \%$ decrease in green fluorescence occurred with the $\mathrm{PFA}+\mathrm{G}$ fixation while a stronger reduction in fluorescence was produced by formalin and freezing. With the present data, and given that PFA is the fixative of choice for fluorescent in situ hybridization (Wallner et al., 1993) and that the PFA+G protocol has been seen to reduce the variability in DNA analyses of the microbes (Jacquet et al., 1998b), we tend to recommend that protocol for cell fixation of prokaryotes.

\section{Staining}

The length of time of cells incubation with the fluorochromes to attain optimal staining prior to FC analysis varies with each type of compound. The recommended incubation time for DAPI and HOECHST 33342 is at least $1 \mathrm{~h}$ (Robertson and Button, 1989) or more (Campbell et al., 1994; and Monfort and Baleux, 1994, stained for $2 \mathrm{~h}$ ), although one of the advantages of HOECHST over DAPI was its lower staining time. The newer blue stains require much lower times, usually less than 15 min (del Giorgio et al., 1996; Marie et al., 1996; Veldhuis et al., 1997). The behavior of some of these stains is quite interesting. For example, Li et al. (1995) used TO-PRO 1 to stain and count all bacteria, but because this fluorochrome is marketed as cell-impermeant by the manufacturers (Haugland, 1999), these authors used fixed and permeabilized cells which quickly took up the stain. But on fresh samples, TO-PRO 1 stains only a fraction of the cells in the first minute, and this number slowly increases until most of the population has been stained within the next 15-20 min. The mean fluorescence per cell is very high for the cells that have been stained in the first minutes and decreases expo- 
nentially afterwards (del Giorgio et al., in press). The interpretation is that only cells with damaged membranes allow the stain to enter the cell and bind to the nucleic acids, while later all cells have their outer membranes stained with less fluorescence.

Staining is sometimes done with the addition of buffers (acting also as cell permeants), such as Triton X-100 (Button and Robertson, 1993; Li et al., 1995), TE buffer (Marie et al., 1996), EDTA or EGTA (Kaprelyants and Kell, 1992; LópezAmorós et al., 1995b). The reason would be that some of the dyes are very sensitive to ionic strength (Marie et al., 1997; Veldhuis et al., 1997). Some authors, however, have found these treatments unnecessary and even detrimental because Triton X-100 generates background fluorescence (Monger and Landry, 1993) and reduces cell autofluorescence (Marie et al., 1996). Interestingly, Marie et al. (1999) report the need for Triton pretreatment to stain live samples with SYTO 13, but not to stain fixed samples, while Comas and VivesRego (1997) found no need for pretreatment to stain bacteria with SYTO 13. Finally, Lebaron et al. (1998) report increased cell-specific fluorescence of the SYTO stains when incubated in the presence of $30 \mathrm{mM}$ potassium citrate. Given that many authors have successfully stained and counted bacteria using SYTO 13 without any pretreatment of the kind discussed here, it is up to each researcher to decided whether he/she has to use it or not. Other fluorochromes, such as TO-PRO 1, that are inherently cell-impermeant, will require some kind of permeabilization pretreatment.

Some authors have suggested that samples should undergo RNAse treatment before the addition of the nucleic acid stains, to eliminate the confounding effect of RNA-induced fluorescence. This is mandatory if one is interested in the cell cycle of the prokaryotes and wants to infer growth rates from those data (e.g. Vaulot et al., 1995), but it is not necessary for regular enumeration of chemotrophic bacteria. Since these organisms do not seem to divide at once, cell cycle analysis for growth rate determination seems not to be possible (Jacquet et al., 1998b). Furthermore, staining with SYTO 13, TOTO-1, TO-PRO 1 and YOYO 1 of planktonic bacteria seem to be dependent only on the amount of DNA, with little RNA interference (Li et al., 1995; Guindulain et al., 1997). This is possibly not due to the binding affinities of the stains to DNA and RNA, but probably to the low amounts of RNA in planktonic bacteria or to the physical unavailability of rRNA to the dyes. Bacterial discrimination

Stained bacteria are detected and discriminated from other non-bacterial particles with a combination of light scatter, green and orange or red fluorescence. In addition, the combination of these parameters allows better resolution of the different subpopulations within the mixed bacterial assemblage. It also allows easy identification of particles that can interfere with the counts. The instrument threshold defines the minimum scatter or fluorescence intensity needed to trigger an event that will be processed by the system software. The threshold allows the reduction of both electronic noise as well as unwanted, non-target particles, and it is usually set on the same primary parameter used to discriminate bacterial cells (i.e. green, or blue, or red, depending on the stain used, or the cell autofluorescence). But there will inevitably be some "noise" particles that have a fluorescent level above that threshold. In our experience, relatively large particles with weak autofluorescence can be discriminated well in the Side scatter - Green fluorescence plot (Fig. 1, left). Particles with low fluorescence and low side scatter have a greater potential to interfere with the actual determination of the bacterial density, but these can easily be taken apart in the Red vs. Green fluorescence plot (Fig 1, right) where they appear in a diagonal line with relatively more red fluorescence than that of bacteria (as long as no electronic compensation has been applied). The presence of these noise particles can be seen very clearly also in Figure 5.

\section{Counting}

A few cytometers, such as the Coulter XL and the Ortho Cytoron Absolute, are equipped with devices that exactly control and record the volume of sample that circulates in front of the laser. But most cytometers have no way of exactly controlling the flux of sample, and therefore, the number of particles detected in a cytometric analysis cannot be directly related to a given sample volume to obtain an estimate of particle density. There are at least three ways of obtaining absolute counts in that case: i) a known amount of reference beads can be added (Cantineaux et al., 1993), ii) the flow can be calibrated each day of work, or iii) the samples can be weighed before and after the run. The last alternative is very time consuming, and in addition, it may be less accurate, because there may be some back- 


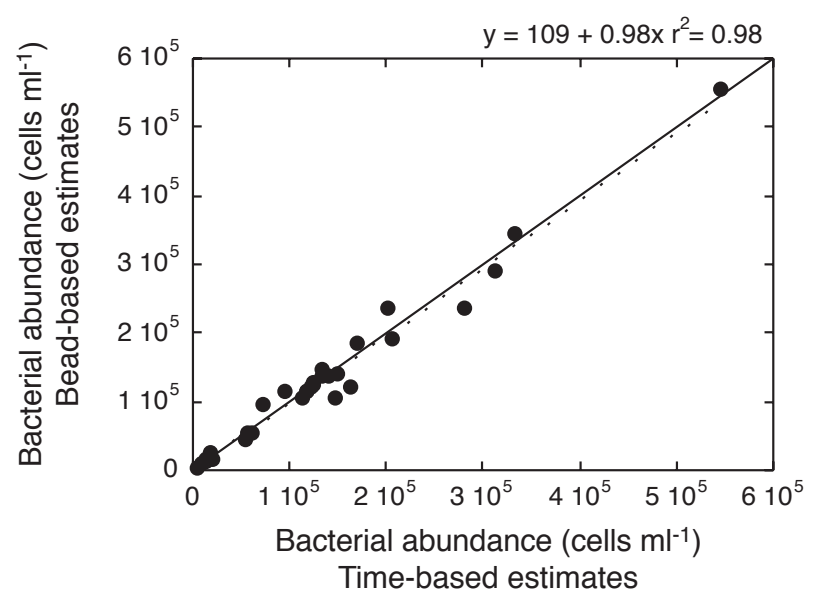

FIG. 3. - Comparison of bacterial concentrations obtained from the relationship of cells detected to the number of beads detected (the beads coming from a solution of known concentration added as internal standards: "bead-based"); and bacterial concentrations calculated from the sample delivery rate of the machine (calibrated gravimetrically at the beginning of the session: "time-based").

flow of sheath fluid into the tube that confounds the actual sample volume processed. Alternative ii) (daily calibration) gives good results but requires an extremely stable instrument. Calibration of the flow can be done easily by weighing a tube containing water, processing various volumes through the cytometer, estimating the time needed for each volume to go through, and then weighing the tube again. Many researchers, thus, use alternative i) (reference beads), because it is accurate, fast and in addition to allowing absolute counts, it also provides an internal standard that can be used to assess instrument performance and to standardize scatter and fluorescence measurements for quantitative applications. However, the beads have to be counted each day of work, sometimes get contaminated with bacteria, and have to be sonicated to avoid aggregation. In our laboratory, the first two of the methods cited above (reference beads and flow calibration) offer highly similar estimates of bacterial abundance (Fig. 3 ). The bead stock is dispensed to each sample to a final bead density that is about $1-10 \%$ of the expected density of target cells. For a regular bacterioplankton sample with an abundance of $10^{6}$ cells $\mathrm{ml}^{-1}$, a final bead density in the sample of 1 to $5 \times 10^{5}$ beads $\mathrm{ml}^{-1}$ is appropriate. An accurate measurement of the reference bead density in the stock solution is of key importance and must be done on a routine basis. Larger beads $(>2.0 \mu \mathrm{m})$ can be counted in a Coulter particle analyzer, but this method is less effective for the smaller beads which are generally used for bacterial work. Alternatively, bead density can be determined using regular epifluorescence microscopy, but this is time consuming and not particularly accurate. A more effective approach is to use a primary reference bead solution where the bead density is precisely known, and to compare this to the working bead solution using the flow cytometer. Primary reference bead solutions are commercially available (i.e.TrueCount, Becton Dickinson).

There are other issues to consider when counting cells, in addition to estimating the volume of sample processed. Bacteria are found in plankton in concentrations varying from $10^{5}$ up to $10^{7}$ cells $\mathrm{ml}^{-1}$. A reasonable sample rate of $10 \mu 1 \mathrm{~min}^{-1}$ (see Table 2), translates into a rate of cell passage through the laser of hundreds to thousands of cells. We often add beads to the sample, and there are other particles which are not bacteria ("noise") in the same sample, all of which contribute to the events detected by the instrument. The light scattered and emitted by each
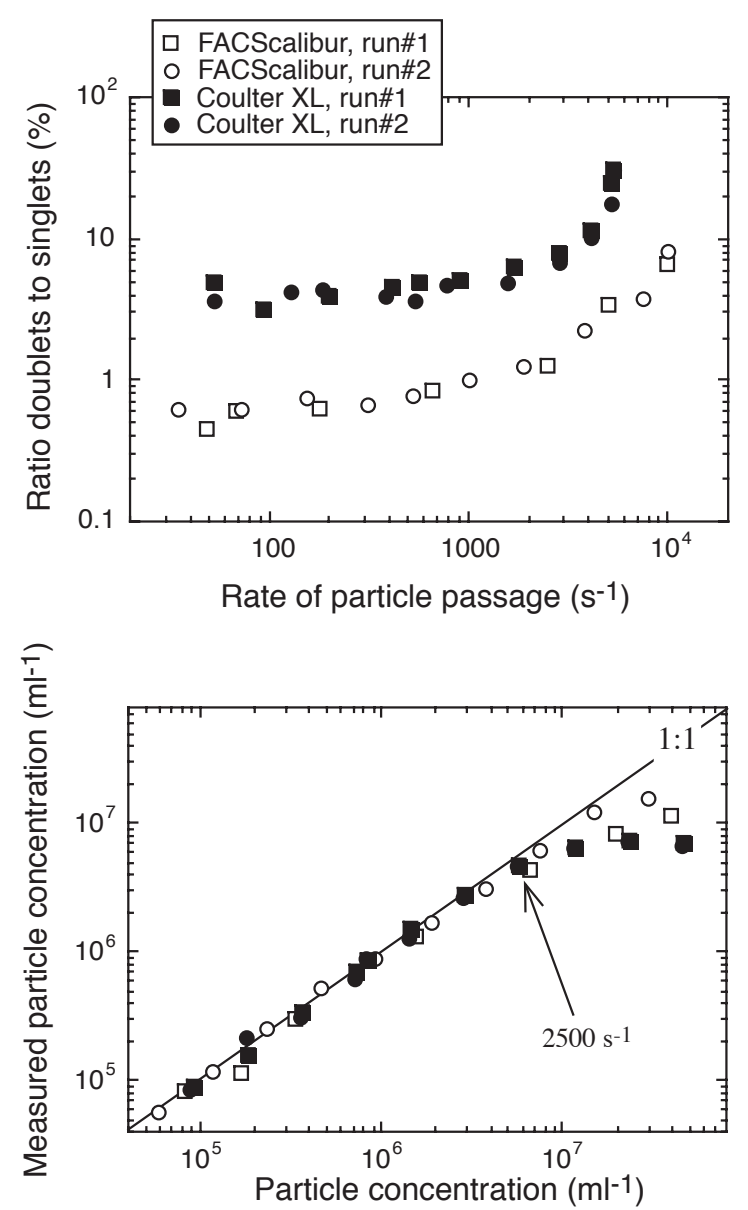

FIG. 4. - Effects of the speed of particle passage through two different flow cytometers (Coulter XL and Becton and Dickinson's FACScalibur). The speed was changed by serially diluting a fluorescent bead solution: Upper panel, the amount of beads detected as doublets. Lower panels, relationship between the actual particle concentration and the flow cytometrically measured particle concentration. 
particle must be collected and converted to an electrical current which must then be digitized by the electronic system, and there are limits to how many of these events a system can effectively handle. In addition, when too many particles go through the cytometer, there is a greater probability that two particles will pass together and be considered by the electronic system as a single larger particle. This phenomenon is called coincidence, and tends to become significant at concentration levels above 2.5 $10^{6}$ cells $\mathrm{ml}^{-1}$ (Marie et al., 1996) which translate to count rates of 1000 - 1400 events s ${ }^{-1}$ (del Giorgio et al., 1996; Marie et al., 1999; Cristina X.P., pers. com.). Samples with higher concentrations have to be diluted either in filtered water, in buffer (Marie $e t$ al., 1999) or in $\mathrm{dH}_{2} \mathrm{O}$ if the samples are fixed (authors' obs.). We have been succesful at enumerating bacteria from solar salt ponds where they are at concentrations above $10^{7} \mathrm{ml}^{-1}$ in salinities around 250\% (Gasol and Pedrós-Alió, unpublished). Dilution of the PFA-fixed sample in $\mathrm{dH}_{2} \mathrm{O}$ served here two purposes: to reduce coincidence and simultaneously to reduce salinity so that salt did not interfere with the nucleic acid stain. Some researchers, however, are routinely counting at rates at or above 2000 $\mathrm{s}^{-1}$ (e.g. Porter et al., 1993). One way of empirically determining the level of coincidence for a given instrument is by means of a bead solution serially diluted to mimic varying particle concentrations (Fig. 4). By increasing the bead concentration and, thus, the rate of particle passage, the amount of doublets (two particles seen as one) increases exponentially (Fig 4a). By relating then the observed particle concentration to the expected concentration, we were able to find out the limits of a FACScalibur and of a Coulter XL, which were very similar and broke out at particle passage rates of around $2000 \mathrm{~s}^{-1}$, equivalent to total particle concentrations of several million particles per ml. Even though this procedure can be used to find out the limits of any machine, it will always be safe to keep the rates of particle passage below the $1000 \mathrm{~s}^{-1}$.

\section{PLANKTONIC BACTERIAL HETEROGENEITY}

As emphasized above, one of the main advantages of enumerating planktonic bacteria by flow cytometry is the possibility of further discriminating distinct fractions of bacteria within mixed assemblages, based on their optical properties. In addition to bulk density it is thus possible to explore the heterogeneity of bac- terial communities (i.e. Kell et al., 1991; Davey and Kell, 1996), and by measuring "cytometric diversity" (Li, 1997; Troussellier et al., 1999) to finally open the "bacterial black box" that dominated the ecology of planktonic microbes in the past.

\section{Phototrophs vs. heterotrophs}

The most elemental differentiation among planktonic prokaryotes is that of phototrophs vs. chemotrophic bacteria. Phototrophs have pigments that can be excited by the blue line of the lasers and fluoresce red or orange, distinct from the usual fluorescence emitted by the DNA stains (blue or green, Table 1, see also Veldhuis and Kraay, 2000). Synechococcus, with a larger size than most heterotrophic bacteria and pigments which emit orange fluorescence has always been easy to differentiate from other prokaryotes in epifluorescence microscopy, and this is also true for FC. But a major ecological advancement was the discovery of Prochlorococcus (Chisholm et al., 1988), which had been confounded as a chemotrophic bacteria in microscopic enumerations (Sieracki et al., 1995) but could be discriminated using FC. This development changed some of the perceptions we had about the role of picoplankton and the microbial food web in the fluxes of carbon and nutrients in the ocean, because of its large contribution to community biomass (Campbell et al., 1994) and primary production (Vaulot et al., 1995). Our understanding of these autotrophic prokaryotes is not yet complete, as little is known about the rates of in situ protozoan grazing on Prochlorococcus (Reckermann and Veldhuis, 1997), and about the possibility that these organisms could be mixotrophs. Recently, for example, it has been shown that the cells of Prochlorococcus, even though divide synchronized to the light:dark periods like most pico- and nanoalgae, can divide several times in a row, with rates exceeding $1 \mathrm{~d}^{-1}$ (Shalapyonok et al., 1998).

As discussed above, double laser excitation is required to completely resolve Prochlorococcus when staining with DAPI or HOECHST (Monger and Landry, 1993), but a single argon laser can be used to detect auto- and chemotrophic bacteria because pigment emission is sufficiently distinct from the emission of most blue-excitable stains. In very stable oligotrophic surface waters their fluorescence is so low, that special modifications in the flow cytometers have been devised to detect these cells (i.e. Campbell and Vaulot, 1993). Olson et al. 

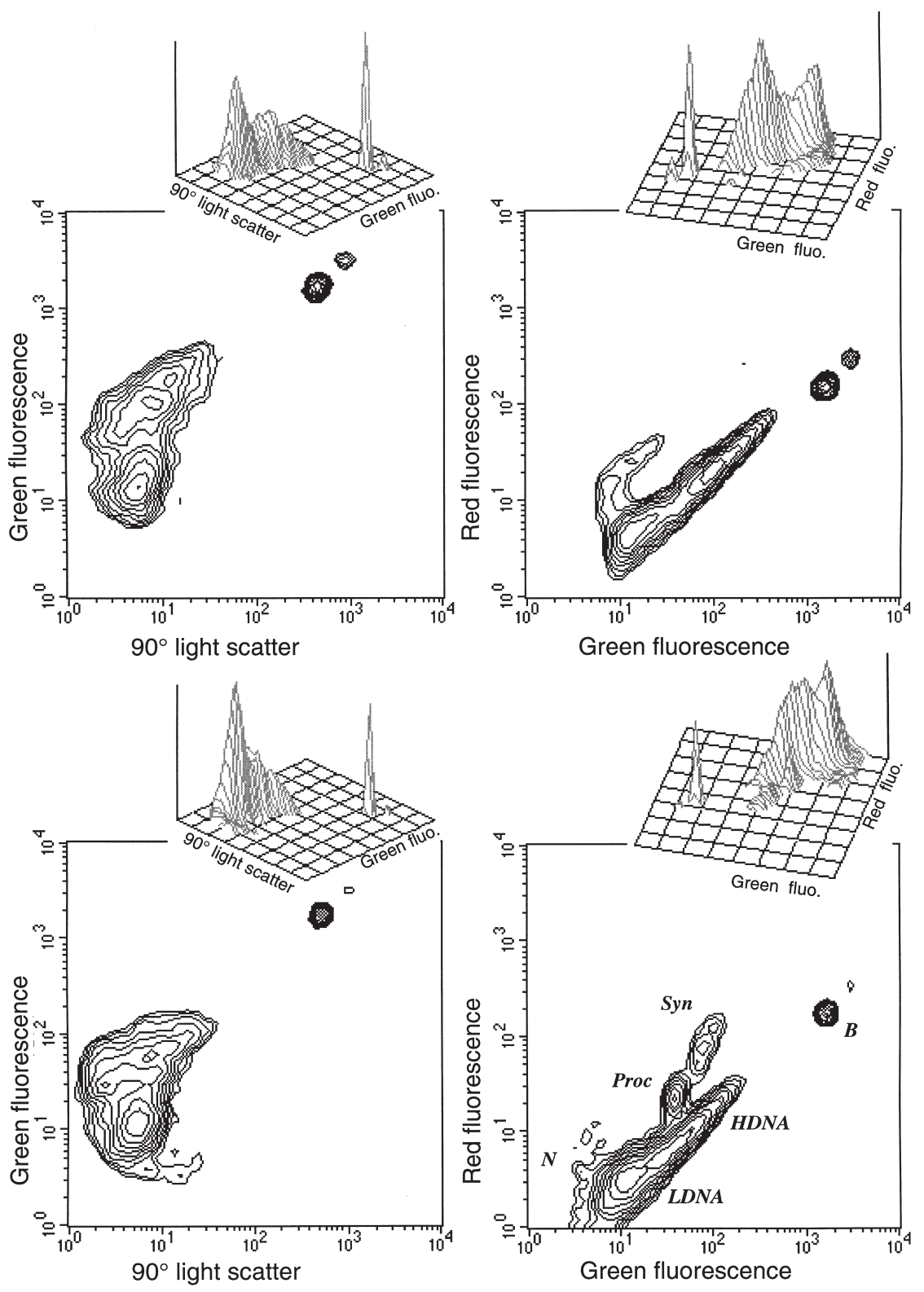

FIG. 5. - Flow cytometric analysis of a coastal (upper) and an open ocean (lower) Atlantic sample after staining with $5 \mu$ M SYTO 13. The panels present contour density plots of 10000 acquired events. In the left side of the graphs, a representation of $90^{\circ}$ light scatter (SSC or WALS) vs. green fluorescence (FL1 in our instrument). In the right side, a representation of green fluorescence vs. red fluorescence (FL3 in our instrument). As in Fig.1, no electronic compensation was applied to the fluorescences, and slightly more voltage was applied to the FL3 photomultipliers than to the FL1 photomultipliers. One step of data smoothing was applied, and a threshold of $1 \%$ eliminated isolated data for these contour density plots. Interpretation of the different subpopulations that appear is as described in Fig.1: B: Yellow-green $1 \mu \mathrm{m}$ Polysciences latex beads. N: electronic noise. HDNA: Bacteria with High DNA content . LDNA: Bacteria with Low DNA content. Syn: Synechococcus. Proc: Prochlorococcus.. Insert in the graphs, a three-dimensional representation of the same data. Note that the 3-D representation of the FL1 vs. FL3 plots has been turned around to show the peaks of the photosynthetic prokaryotes.

(1990) suggested the decrease of the laser beam spot and the decrease of the sheath fluid pressure to produce better signals. Other modifications were suggested by Dusenberry and Frankel (1994). When the autofluorescence of the Prochlorococcus is stronger, typically in cells sampled from deeper waters, they can easily be discriminated from chemotrophic bacteria in a plot of Red vs. Green fluorescence (Fig. 5).
Note the presence of abundant Prochlorococcus and Synechococcus populations in an open Atlantic sample (Fig. 5, lower) as compared to an estuarine sample where chemotrophic bacteria were several-fold more abundant than phototrophic bacteria (Fig. 5, upper). When the autofluorescence is weak, as is typical in cells from surface samples, or when in doubt, a double run of the sample, before and after 
staining, is necessary (i.e. Marie et al., 1997). Zubkov et al. (1998) suggested another way to discriminate Prochlorophytes, based on the fact that these organisms typically showed a sharp peak in DNA fluorescence (green fluorescence of TOTO) caused by higher DNA content per cell than similarly sized chemotrophic bacteria. In case the prochlorophytes' autofluorescence is extremely low, and only a portion of the Prochlorococcus population appears above the red fluorescence threshold, the population is assumed to have a normal distribution of red fluorescence, and the hidden portion can be extrapolated (i.e. Partensky et al., 1996; Blanchot and Rodier, 1996).

Other phototrophic bacteria (i.e. Chlorobium, Chromatium, etc.) can also be discriminated from chemotrophic bacteria based on the fluorescence characteristics of the various bacteriochlorophylls of each of these groups (Cristina X.P., pers. com.). Flow cytometric detection of phototrophic picoplankton in freshwater is still in its infancy, and some surprises can be expected (e.g. Corzo et al., 1999).

\section{DNA content of individual bacteria}

The DNA content of bacteria has been one of the parameters of interest for researchers from the very beginning of the flow cytometric analyses (Bailey et al., 1977; Paau et al., 1977). In fact, the study of the growth cycle of bacteria was one of the reasons to probe their DNA with specific stains, which was done with the help of an antibiotic, rifampicin, to inhibit cell replication producing bacteria with 1,2 , 4, or 8 chromosomes (Steen et al., 1990). This has sometimes been used as a standard for DNA content of bacteria in some applications (Button and Robertson, 1993), although other studies have used chicken red blood cells as standards (Vaulot et al., 1995; Veldhuis et al., 1997).

As discussed above, the nucleic acid stains may not only stain DNA, but also RNA and most show some degree of non-specific staining to other macromolecules and membrane surfaces. However, in bacterioplankton samples most of the fluorescence appears to be directly linked to DNA, and this may be due to the fact that fluorescence emission of many nucleic acid stains is several-fold higher when bound to DNA relative to the unbound dye or to the nonspecifically bound dye. Observation of light scatter vs. green fluorescence cytograms (Fig. 1 and 5) reveals the presence of clearly separated subgroups of bacteria which have roughly similar side scatter but differ significantly in green fluorescence, suggesting differences in per cell DNA contents. While almost always at least two groups can be differentiated (Fig. 5), three (Fig. 1) or more (e.g. Troussellier et al., 1999) groups can sometimes be discriminated. Sieracki and Viles (1992) already detected with image cytometry some bacterial cells which had different DAPI-staining characteristics, particularly a clear group with low DAPI-staining. A similar low fluorescence group of cells appeared in the flow cytometry analysis of Monger and Landry (1993) of Kaneohe Bay bacteria. Since that paper, the two groups of bacteria have been seen in TOTO and TO-PRO stained marine bacteria ( $\mathrm{Li}$ et $a l .$, 1995), in DAPI-stained freshwater bacteria (Button et al., 1996) and in SybrGreen I-stained marine bacteria (Marie et al., 1997). We have found the two subgroups of bacteria appearing in all samples analyzed from oligotrophic high-mountain lakes to eutrophic reservoirs, and from estuaries to open ocean seas. We have also seen these subgroups in SYTO13, SybrGreen I and PicoGreen-stained samples and we thus believe that the presence of these subgroups is a characteristic feature of planktonic bacteria. The third bacterial subgroup identified by Marie et al. (1997), Group II according to these authors, is not always present in the samples. Fig. 1 shows an example where it is possible to see that subpopulation, but in the samples presented in Fig. 5 is not possible (Fig. 5, upper) or very difficult (Fig. 5, lower) to differentiate.

Li et al. (1995) labeled the two subgroups as Group I (the low fluorescence ones) and Group II (the high fluorescence ones) bacteria. We, however, consider more appropriate to label these subpopulations as High DNA bacteria and Low DNA bacteria (Gasol and Morán, 1999; Gasol et al., 1999). Although these fractions have been repeatedly observed in most aquatic ecosystems, little work has been performed to date to characterize their composition and level of metabolic activity. Li et al. (1995) showed that their High DNA counts were better correlated to chlorophyll $a$ than their Low DNA bacterial counts and that the fluorescence difference between the two groups was positively related to chlorophyll. In a follow-up paper, Jellett et al. (1996) compared the \%HDNA (which they called "Active cell index") to tritiated substrate uptake rates and found patterns that were similar but not entirely coherent. They also determined that the High DNA cells had on average 5 times more DNA per cell than did the Low DNA cells. The work of Li 

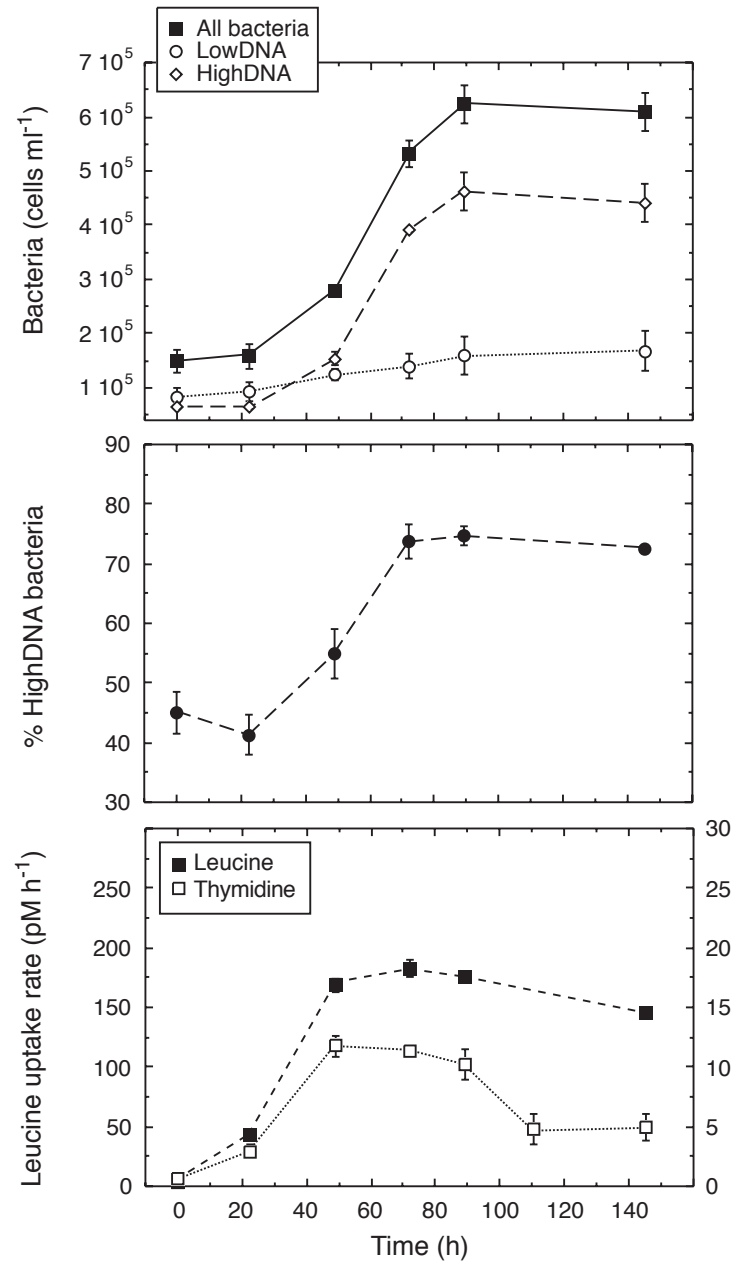

FIG. 6. - A dilution-growth experiment with open North Atlantic water. Water was filtered through $0.8 \mu \mathrm{m}$ and diluted 2:10 with 0.2 $\mu \mathrm{m}$-filtered water. Upper panel: evolution of total bacteria, HighD NA bacteria and LowDNA bacteria. Central panel: evolution of the $\%$ contribution of HighDNA bacteria to total bacteria. Lower panel: Evolution of the uptake rates of Leucine and thymidine (standard methods as described in Kemp et al. 1993). Average plus standard error of two replicated bottles. Data courtesy of Carlos Pedrós-Alió.

and colleagues pointed towards the idea that the \%HDNA values had potential for being a useful index of bacterial growth. In a dilution-growth experiment, Li et al. (1995) showed that High DNA bacteria grew three times as fast as Low DNA bacteria. Fig. 6 presents a similar experiment in which the uptake of tritiated thymidine and tritiated leucine was also followed. Although the Low DNA bacteria showed some growth, almost all the growth of the population, and thus the uptake of the tritiated precursors that occurred a few hours before the increase in cell numbers, was done by the High DNA bacteria which are clearly the active and dynamic members of the bacterioplankton community. Further evidence of the meaning of these two subpopula- tions has been obtained in filtration experiments in which size-selective filtration enriches the filtrate in Low DNA bacteria (Gasol and Morán, 1999) and the direct comparison of the values of High DNA bacteria with those of "Live" (Molecular Probes' BacLight Live/Dead staining kit) bacteria and with those of NuCC (nucleoid containing bacteria, Zweifel and Hagström, 1995) that shows a strikingly good correspondence between average values and between directly estimated rates of change through time of NuCC, "Live" and High DNA bacteria (Gasol et al., 1999). Recently, Servais et al. (1999) labelled bacteria with radioactive leucine, sorted bacteria from both groups, and encountered that High DNA bacteria had ten times more specific activity than Low DNA bacteria, and were responsible for most of the community total Leucine uptake. These authors estimated Low DNA bacteria growth rates of $0.0005 \mathrm{~h}^{-1}$ vs. $0.036 \mathrm{~h}^{-1}$ for the High DNA bacteria at the begining of their experiment.

The \% HDNA seemed to decrease with the presence of bacterial predators, and that would be consistent with the known size- and activity-selective grazing behavior of flagellates (Jürgens and Güde, 1994; Gasol et al., 1995).

\section{Bacterial size determination}

Light scattering at different angles is related to a wide range of cellular characteristics, but scattering at small angles is mostly a function of particle volume and secondarily shape (Latimer, 1982). Relationships between forward light scatter and bacterial size have been reported, although not always involving bacterioplankton (Robertson and Button, 1989; Allman et al., 1990; Steen, 1990; DeLeo and Beveye, 1996; Troussellier et al., 1999), but some authors have also reported an almost complete lack of relationship between forward and side scatter and bacterial size, either throughout the growth cycle of bacteria (López-Amorós et al., 1994; Vives-Rego et al., 1994) or in natural samples (Christensen et al., 1993; Heldal et al., 1994). Relationships between the total amount of protein in a culture and the amount of light scattered have also been established (i.e. Steen and Boye, 1981). Light scattering is a complex function of cell size, shape, structure, and refractive index, and different instruments and even fixatives, may yield significantly different histograms of the same sample as a function of relatively minor changes in detection geometry. This led Allman et al. (1992) to predict that the relationship 
between size and light scattering would break down when comparing different species.

In spite of these shortcomings, Button and Robertson (1993) have made use of forward scatter to estimate bacterial size. These authors (Robertson and Button, 1989) presented a good relationship between FSC and bacterial volume for sizes between 0.22 and $1.3 \mu \mathrm{m}^{3}$, well above those of planktonic bacteria (which are of sizes $0.03-0.1$ $\left.\mu \mathrm{m}^{3}\right)$. Koch et al. (1996) presented the theoretical basis of their approach: forward scatter was chosen over side scatter because of its "far greater signal intensity and insensitivity to subcellular structure". Light scattering theory, for particles of the size range of bacteria, was used to present a theoretical algorithm that should be calibrated for each type of machine. The algorithm predicts size as a nonlinear function of cell volume (in fact, it is an exponential function that has a grade 3 polynomial with the logarithm of light scatter as exponent). The relationship seemed to fit well an empirical relationship based on forward scatter of bacterial cultures and beads, corrected for the different refraction indices of beads and bacteria (Button et al., 1996). The method has been used to estimate the biomass of "small" bacteria (Robertson et al., 1998), although these bacteria were still considerably larger than the average bacterioplankton (bacterial size range > $0.13 \mu \mathrm{m}^{3}$, see Table 4 in Robertson et al., 1998).

The conflicting results reported in the literature on the relationship between cell size and light scattering may be due in part to hardware differences among the instruments used. Most current bench top cytometers are equipped with a photodiode to capture the light scattered in the forward direction, which is less sensitive than the photomultiplier tubes typically used to collect side scatter and fluorescence. It is our experience that in both FACSCalibur and Coulter, the dispersion of the reference beads is much greater in forward scatter than it is in any other parameter. Cytograms included in recent published papers also often show the same large dispersion of beads as well as of target cells in forward scatter. This limits the usefulness of forward scatter and possibly weakens any relationship with cell size. Some instruments, however, have been equipped with photomultiplier tubes protected by screens to capture light scattered in forward angles, and this probably greatly increases the sensitivity of this parameter. On the other hand, the range of bacterial cell sizes used to establish an empirical relationship between cell size and scatter is also critical.
The evidence to date is that forward (and perhaps side) scatter is a good index of bacterial cell volume for larger, typically cultured, bacteria but there is still no convincing evidence that forward scatter can be used to estimate the size of natural bacterioplankton cells in the 0.03 to $0.1 \mu \mathrm{m}^{3}$ range.

An alternative to using scattered light as an index of bacterial size, is the use of the fluorescence of DNA-bound stains (Steen and Boye, 1981). Veldhuis et al. (1997) have found that DNA content, as estimated with PicoGreen, varies with cellular $\mathrm{C}$ and $\mathrm{N}$ content, at least for pico- and nanoalgae. We have also found that filters which are known to be sizeselective (Glass fiber and cellulose ester filters) remove a large portion of the SYTO-stained cells with the strongest green fluorescence (Gasol and Morán, 1999), offering indirect support to the relationship found by Veldhuis et al. (1997). Troussellier et al. (1999) also found cell size to be related equally to SSC and to DNA fluorescence. We recently found a very good relationship between image analysis measurements of planktonic bacterial size (in the range $0.03-0.09 \mu \mathrm{m}^{3}$ ) and the average green SYTO 13 fluorescence per cell (Fig. 7, with data from Prairie. et al., in prep.) suggesting that indeed, DNArelated fluorescence can be used as a surrogate of bacterial size, although some calibration is needed. We have been using the relationship in Fig. 7 in a wide variety of systems and have found very reasonable estimates of bacterial size except in the most eutrophic environments where long bacterial filaments were abundant (J.M. Gasol and K. Simek, unpublished). Calibration with bacteria of known sizes is required

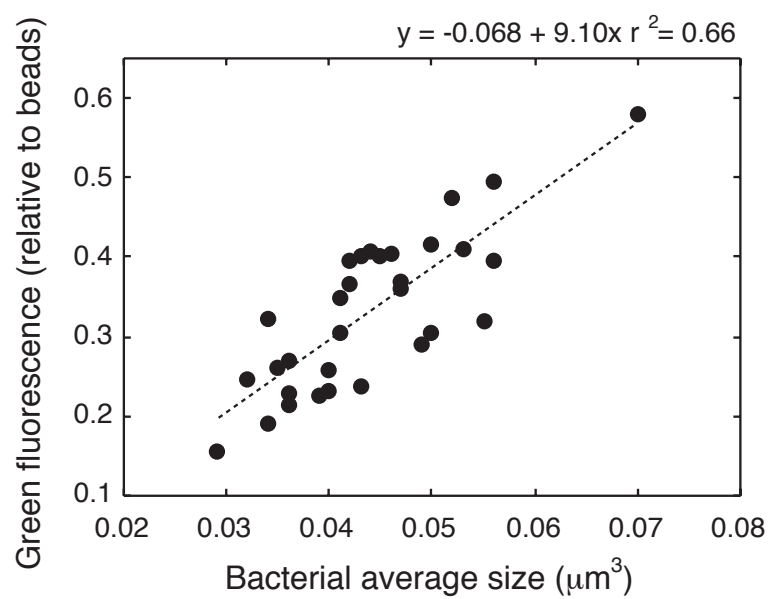

FIG. 7. - Relationship between average bacterial size (obtained by image analysis of DAPI preparations following the procedure of Massana et al. 1997), and average fluorescence (relative to beads) of the SYTO 13-stained sample run in a FACSort flow cytometer. Samples from the plankton of Lake Cromwell (Quebec). Data from Prairie Y. et al. (in prep.). 
also if we are using DNA-related fluorescence as a means of measuring bacterial size.

It is also worth citing the work of Zubkov et al. (1998), who have used an alternative way for measuring bacterial size of open ocean samples, later followed by others (Gin et al., 1999). These authors filtered the sample through different pore-sized filters (from 0.4 up to $1 \mu \mathrm{m}$ ), measured bacterial abundance in the filtrates, and regressed abundance to filter size. The value that let through $50 \%$ of the bacteria was taken as the average size of the population. Even though the method is extremely indirect, these authors found that the average bacterium in the open central Atlantic had $19 \mathrm{fg} \mathrm{C}$, a value very close to that generally used as average carbon content of oceanic bacteria (e.g. Lee and Fuhrman, 1987; Ducklow et al., 1993).

Given that microbial ecologists are often interested directly in the values of bacterial biomass rather than in bacterial size, Zubkov et al. (1999) proposed the use of the protein stain SYPRO to directly evaluate the total amount of bacterial protein and, thus, obtain a better surrogate of bacterial biomass (protein is usually more than $50 \%$ of bacterial dry weight). SYPRO staining of bacterial cultures correlated well with directly measured protein. DNA content also seemed to covary with bacterial protein in most of the assayed bacterial species.

\section{Single-cell activity}

Researchers interested in quantifying the effects of antimicrobial agents on bacterial growth and viability promoted the development of probes that could be used to assess the physiological state of individual bacterial cells. The objective was to discriminate cells with potential for growth (also called, "viable", "active" or "live") from cells that had completely lost this potential ("non-viable", "injured" or "dead") or

TABLE 3. - Dyes used for monitoring bacterial viability by flow cytometry

\begin{tabular}{|c|c|c|c|c|}
\hline Stain & Mode of action & Exc/Em & applied in & References \\
\hline AO (acridine orange) & $\begin{array}{l}\text { Different color when linked } \\
\text { to DNA or other things }\end{array}$ & $460 / 650$ & cultures & $\begin{array}{l}\text { Nishimura et al. } 1995 \\
\text { Darzynkiewicz and Kapuscinski 1990, } \\
\text { McFeters et al. } 1991\end{array}$ \\
\hline PI (propidium iodide) & excluded by living cells & $536 / 623$ & $\begin{array}{l}\text { cultures } \\
\text { cultured bact } \\
\text { in seawater }\end{array}$ & $\begin{array}{l}\text { Jepras et al. } 1995 \\
\text { López-Amorós } \text { et al. } 1995 \mathrm{~b}\end{array}$ \\
\hline EthBr (ethidium bromide) & excluded by living cells & $510 / 595$ & cultures & Paau et al. 1977, Pinder et al. 1990 \\
\hline $\begin{array}{l}\text { Oxonols (JC-1, oxonol VI, } \\
\left.\operatorname{DiBaC}_{4}(3)\right)\end{array}$ & $\begin{array}{l}\text { accumulate when energy- } \\
\text { defficient }\end{array}$ & $488 / 525$ & cultures & $\begin{array}{l}\text { Mason et al. 1995, Deere et al. 1995, } \\
\text { Jepras et al. 1995, López-Amorós et al. 1995a } \\
\text { Comas and Vives-rego 1997, Beck and } \\
\text { Huber } 1997\end{array}$ \\
\hline $\begin{array}{l}\text { FDG (fluorescein- } \\
\text { galactopyranose) }\end{array}$ & $\begin{array}{l}\text { Activity of the enzime } \\
\beta \text {-galactosidase }\end{array}$ & $494 / 518$ & cultures & Nir et al. 1990, Miao et al. 1993 \\
\hline Fluorescein diacetate (FDA) & cleaved by intracellular enzims & s $492 / 517$ & cultures & Diaper et al. 1992 \\
\hline $\begin{array}{l}\text { CFDA, Chemchrome B, } \\
\text { calcein blue AM, SFDA... }\end{array}$ & cleaved by intracellular enzims & $(488-520 / 560)$ & cultures & $\begin{array}{l}\text { Diaper and Edwards 1994a, Jepras et al. } 1995 \text {, } \\
\text { Jacobsen et al. 1997, Beck and Huber } 1997\end{array}$ \\
\hline & & & $\begin{array}{l}\text { compost } \\
\text { freshwater }\end{array}$ & $\begin{array}{l}\text { Diaper and Edwards 1994b } \\
\text { Porter } \text { et al. } 1995 \text { a }\end{array}$ \\
\hline CTC & $\begin{array}{l}\text { indicator of respiratory-chain } \\
\text { activity }\end{array}$ & $480 />585$ & freshwater & $\begin{array}{l}\text { Kaprelyants and Kell 1993a, López- } \\
\text { Amorós et al. } 1997 \\
\text { del Giorgio et al. 1997b, Yamaguchi and } \\
\text { Nasu } 1997\end{array}$ \\
\hline Rh123 (rhodamine 123) & accumulated in live cells & $510 / 580$ & $\begin{array}{l}\text { marine } \\
\text { cultures }\end{array}$ & $\begin{array}{l}\text { López-Amorós et al. 1998, Sieracki et al. } 1999 \\
\text { Diaper et al. 1992, Davey et al. 1993, } \\
\text { Kaprelyants and Kell } 1992\end{array}$ \\
\hline $\begin{array}{l}\text { Cyanine dyes }\left(\mathrm{DiOC}_{6}(3),\right. \\
\left.\operatorname{DiOC}_{2}(3) \ldots\right)\end{array}$ & accumulated in live cells & $\begin{array}{l}488 / 520-560 \\
488 />600\end{array}$ & $\begin{array}{l}\text { cult bact in SW } \\
\text { cultures } \\
\text { cultures }\end{array}$ & $\begin{array}{l}\text { López-Amorós et al. } 1995 \mathrm{~b} \\
\text { Mason et al. } 1995, \text { Monfort and Baleaux } 1996 \\
\text { Novo et al. } 1999\end{array}$ \\
\hline c-SNARF-1 AM & intracellular $\mathrm{pH}$ & $\sim 488$ / 610 & cultures & Leyval et al. 1997 \\
\hline $\begin{array}{l}\text { Calcafluor white, } \\
\text { Tinopal CBS-X... }\end{array}$ & excluded by living cells & $\begin{array}{l}347 / 436 \\
325 / 430\end{array}$ & $\begin{array}{l}\text { cultures } \\
\text { cultures }\end{array}$ & $\begin{array}{l}\text { Mason et al. } 1995 \\
\text { Davey and kell } 1997\end{array}$ \\
\hline SYTOX Green & excluded by living cells & $504 / 523$ & cultures & Roth et al. 1997, Veldhuis et al. 1997 \\
\hline TOPRO-1 & excluded by living cells & $515 / 531$ & freshwater & del Giorgio et al., in press \\
\hline TOPRO-3 & excluded by living cells & $642 / 661$ & cultures & Davey et al. 1999 \\
\hline 16S rRNA probes & attach to ribosomes & - & cultures & Amann et al. 1990; Wallner et al. 1993 \\
\hline DVC* & $\begin{array}{l}\text { live cells elongate when } \\
\text { in presence of } \mathrm{ABs}\end{array}$ & - & $\begin{array}{l}\text { cultures } \\
\text { seawater }\end{array}$ & $\begin{array}{l}\text { Thorsen et al. } 1992 \text {, Joux et al. } 1997 \\
\text { Nishimura et al. } 1995\end{array}$ \\
\hline BacLight Live / Dead & (Syto9 / PI) & - & cultures & Joux et al. 1997, Jacobsen et al. 1997 \\
\hline
\end{tabular}

* DVC: Direct viable count. Samples are incubated with added organics and antibiotics that stop cell division. Active cells elongate without division and can be detected by changes in light scatter. 
cells that had temporarily lost this potential and were in a state of arrested growth ("dormant" or "inactive")(Roszak and Colwell, 1987). Hutter and Eipel (1978) used Erythrosine B to label damaged yeast cells and since then many more viability probes have been put in use for bacteria (Table 3).

There are two broad categories of physiological probes currently in use: 1) Those that indicate the state of membrane integrity or energization, and 2) those that are taken up by the viable cells and then modified intracellularly to yield fluorescent products (McFeters et al., 1995; Nybroe, 1995; Nebevon Caron et al., 1998). Among the first group there are exclusion stains, which do not penetrate intact and healthy membranes because of their molecular structure and size, but do penetrate cells with injured membranes and then stain nucleic acids (i.e. propidium iodide, ethidium bromide, TOPRO-1 and SYTOX). Another group of compounds in this category are potential-sensitive dyes with are actively excluded by cells with membrane potential but stain cells which lack membrane potential (i.e. Oxonols, calcofluor white, Rhodamine 123). The second group includes dyes that are modified chemically so that the active cells become visible. Examples of this category include tetrazolium salts such as CTC, which is reduced to a formazan by the enzymes of the electron transport system, and FDA, which produce a fluorescent product upon intracellular cleavage by active estereases.

The overwhelming majority of physiological probes currently in use are fluorescent and can be used in conjunction with the flow cytometer, with the added benefit of analyzing the probe-conferred fluorescence of great numbers of cells. Not surprisingly, flow cytometry has been extensively used in clinical and environmental microbiology in conjunction with a wide variety of physiological probes to assess bacterial single-cell activity (Edwards, 1996; Davey and Kell, 1996; Nebe-von Caron et al., 1998; Davey et al., 1999). But most probes have intrinsic problems and do not perform under all circumstances, so contradictory results are common in the literature (e.g. Comas and Vives-Rego, 1998). The application of these techniques to ecological problems has lagged considerably behind their use in microbiology, in part because technical difficulties and uncertainties are magnified when the techniques are applied to mixed natural bacterial assemblages. This may explain why relatively few of the wide array of available probes have been used with natural aquatic bacteria (summarized in Table 3), and why there are even fewer studies that have attempted to combine physiological probes with flow cytometry to assess the single cell activity of bacterioplankton. Below are some examples of such applications.

Nishimura et al. (1995) adapted the Direct Viable Count (DVC) method to detect active bacteria by flow cytometry in a marine sample. The method consists in adding organic matter and a cocktail of antibiotics to the sample so that bacterial growth is enhanced but bacterial division is impeded by the antibiotics, so that live and viable bacteria enlarge and can be detected on the basis of the changes in cell size and associated light scatter. The method had been used for bacterial cultures and flow cytometry before (Thorsen et al., 1992; Joux et al., 1997).

Rhodamine123 (Rh123) and Propidium iodide (PI) have been used to monitor the viability of specific bacterial cultures added to seawater (LópezAmorós et al., 1995b) in a double staining protocol. Rh123 is a polar cationic fluorescent dye that mitochondria accumulate in an energy-dependent mechanism while PI stains cells with compromised membranes (Haugland, 1999). Diaper et al. (1992) and Kaprelyants and Kell (1993b) suggested that Rh123 could be used to differentiate viable, nonviable and dormant cells, but most gram-negative bacteria exclude this stain and required permeabilization with EGTA or EDTA and Tris. Several authors have suggested the use of the oxonol $\left(\operatorname{DiBAC}_{4}(3)\right.$, etc.) dyes, which are negative-charged dyes sensitive to membrane potential and preferentially stain cells with unpolarized membranes. Complementary to Rh123, they are nontoxic and do not require EDTA treatment to be used instead of PI (López-Amorós et al., 1995a, 1995b; Deere et al., 1995; Mason et al., 1995; Comas and Vives-Rego, 1997; Nebe-von Caron et al., 1998).

Porter et al. (1995a) tested some viability dyes derivatives from the FDA (CFDA, ChemChrome B, etc.) as an alternative to stains that do not perform well in highly colored lakes. These stains are nonfluorescent but upon intracellular enzymatic cleavage they produce a fluorescence compound that can be detected using flow cytometry. Porter et al. suggested that combinations of these stains could work as viability dyes, and they found viability values ranging from 7 to $75 \%$ of the total count in natural waters, although the authors did not provide any independent control to assess the validity of their findings. Newer and promising protocols, some using combination of dyes (like the BacLight Via- 
bility kit, or the combination of ChemChrome V6 and CSE, Catala et al., 1999) are continously being introduced into the field of microbiology and eventually, if satisfactory, will be tested with natural bacterioplankton.

By far the physiological probe that has been most widely used in combination with flow cytometry to assess single cell activity in natural bacteria has been CTC (5-cyano-2,3-ditolyl tetrazolium chloride), a tetrazolium salt that, when reduced intracellularly by the active bacterial respiratory enzymes, turns into a water insoluble, red fluorescent formazan. There is some evidence that CTC may be toxic to some bacteria (Kaprelyants and Kell, 1993a; Ullrich et al., 1996) at the concentrations used, and might not work in some circumstances (Thom et al., 1993), but has been satisfactorily used to stain active bacteria from cultures (Kaprelyants and Kell, 1993a; López-Amorós et al., 1995a, 1997; McFeters et al., 1995), freshwater plankton (del Giorgio et al., 1997b; Yamaguchi and Nasu, 1997) and marine plankton (López-Amorós et al., 1998; Sieracki et al., 1999). A double staining protocol with SYTO 13 and CTC has been devised but requires a flow cytometer with double laser capabilities (López-Amorós et al., 1998).

In most natural samples treated with CTC there is a wide range of red fluorescence intensities from cells, which is linked to the rate of CTC reduction which in turn is linked to cell metabolic activity. Fig. 8 (upper panels) shows an example of a coastal marine sample that has been incubated with CTC for 2 hours. Even though the bulk of the population is clearly above threshold, there are some cells with weak red fluorescence due to CTC that have been excluded by the red threshold. This same phenomenon has been encountered in different types of samples (López-Amorós et al., 1998; Sieracki et al., 1999) and suggests that the number of active cells obtained by this method underestimates the actual number of cells with low degree of metabolism. In this respect, the main problem of CTC reduction is that, like with most other physiological probes, the threshold of bacterial activity that it detects is not known, so it is difficult to a priori assign ecological meaning to the results. Field and laboratory studies, however, have suggested that CTC is effective in marking the most active portion of the bacterial assemblage (del Giorgio et al., 1997b; Sherr et al., 1999; Sieracki et al., 1999), although there is little doubt that a portion of live cells always score negative to the assay due to their low metabolic activity. Flow cytometry is particularly adequate for enumer- ating the CTC-reducing bacteria because it is more sensitive than the human eye and the microscope, specially in the red region of the spectrum, facilitating lower incubation times (del Giorgio et al., 1997b; Sieracki et al., 1999). In addition, cytometry allows easy quantification of the mean red fluorescence per cell, which is itself related to the degree of cellular metabolism and provides useful additional information (Cook and Garland, 1997; Sherr et al., 1999).

It is clear that bacterial single cell activity in a given aquatic assemblage will vary continuously from high to low metabolism to dormancy to death, so that categorizing cells as simply "active" or "inactive" is probably inadequate. Researchers are increasingly using combinations of several probes to further categorize bacteria into ecologically relevant fractions. For example, Williams et al. (1998) have suggested a procedure for differentiating cells that are active from those that were recently active and those that are dead. The method has not yet been used with flow cytometry, but it certainly could be as it involves stains that have all been used in the past (Table 3). The simple differentiation between High and Low DNA bacteria cited above can also be used to indicate the percentage of highly active bacteria from a planktonic sample (Gasol et al., 1999).

For a comprehensive overview over phytoplankton single cell activity stains and probes, see Jochem (2000).

\section{Phylogenetic heterogeneity}

Recent advances in molecular techniques have greatly increased our ability to discern bacteria belonging to a given taxa or phylogenetic group without the need for cultivation (Amann et al., 1995), with enormous practical advantages for monitoring pathogenic, indicator or bioengineered species in clinical and environmental studies. But the ability to assess the phylogenetic composition of natural bacterial assemblages without need for cultivation has obvious ecological potential as yet another approach to opening the "bacterial black box". Molecular approaches are increasingly being utilized to probe natural bacterioplankton composition, and some of these applications are increasingly being combined with flow cytometry (Amann et al., 1990; Collier and Campbell, 1999). Fingerprinting bacterial communities will probably soon be possible with TOTO-1 staining of bacterial chromosome fragments (i.e. Kim et al., 1999). 

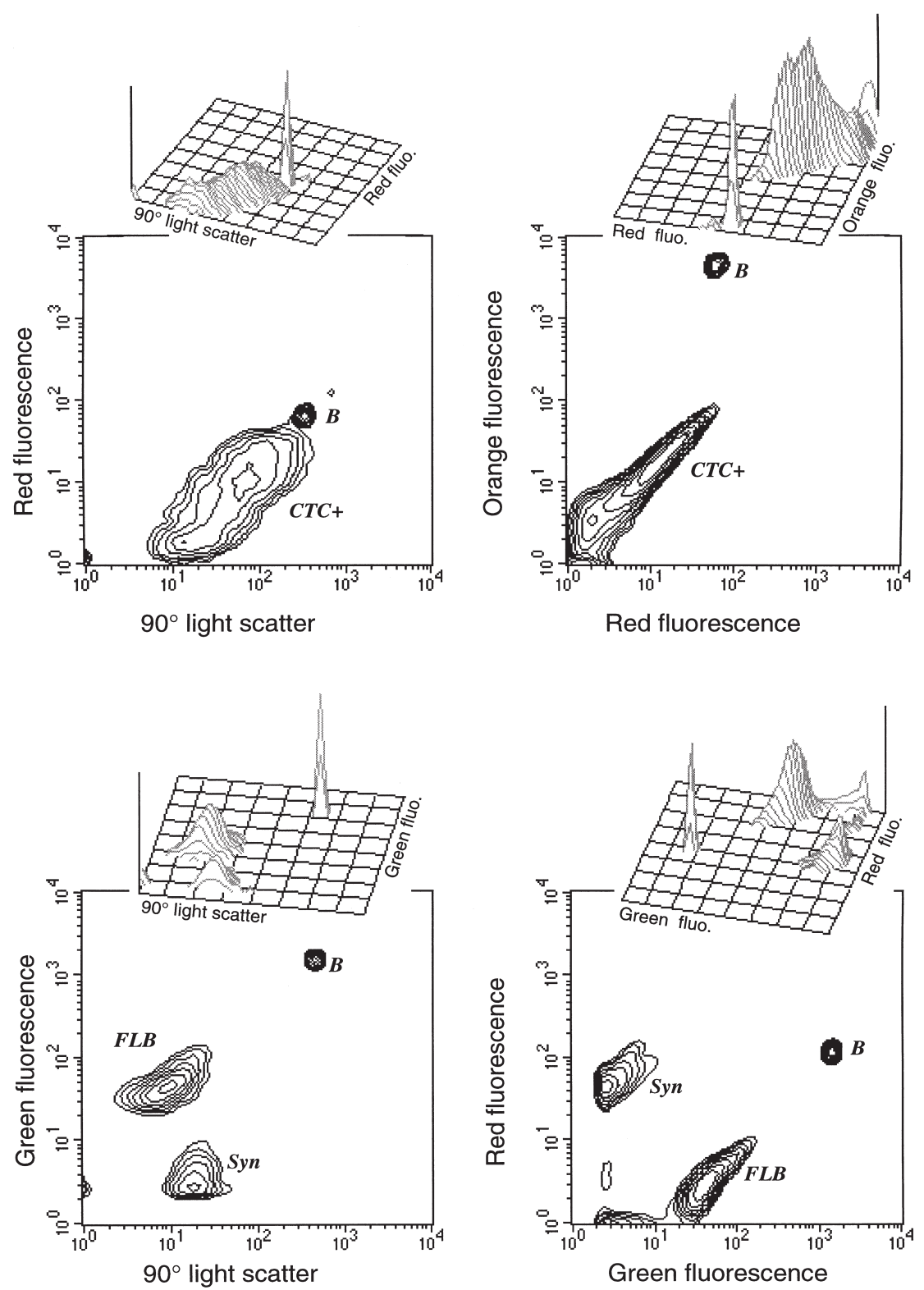

FIG.8. - Upper panels. Flow cytometric analysis of a Mediterranean plankton sample after incubation with 5 mM CTC for a few hours showing the presence of a bacterial population that took up the salt and reduced it to the fluorescent CTF (labeled as CTC+). Yellow beads (B) were included in the run. The panels present contour density plots of 10000 acquired events. In the left side of the graphs, a representation of $90^{\circ}$ light scatter (SSC) vs. red fluorescence (FL3). In the right side, a representation of orange fluorescence (FL2) vs. red fluorescence. Note that the 3-D representation of the FL2 vs. FL3 plot has been turned around to better show that the main peak is separated from the background. Lower panels. Flow cytometric signature of FITC-stained Pseudomonas diminuta (FLB) added as a tracer for grazer experiments to a Mediterranean plankton sample particularly rich in Synechococcus (labeled as Syn). Yellow beads (B) were included in the run. The panels present contour density plots of 10000 acquired events. In the left side of the graphs, a representation of $90^{\circ}$ light scatter (SSC) vs. green fluorescence (FL1). In the right side, a representation of red fluorescence (FL3) vs. green fluorescence. Note that the 3-D representation of the FL1 vs. FL3 plot has been turned around to better show the separation of both populations.

Initial work was done with fluorescently labeled antibodies or lectins (e.g. Vesey et al., 1994). These were used to detect Legionella (Ingram et al., 1982; Tyndall et al., 1985), Bacillus (Philips and Martin, 1983), Salmonella typhimurium (McClelland and Pinder, 1994) and Listeria monocytogenes (Donnelly and Baigent, 1986), with detection limits as low as 20 cells $\mathrm{ml}^{-1}$. Although some nonspecific identification can always occur, detection of 1 positive cell in a background of 10000 negative cells is possible. Fouchet et al. (1993) reviews this area of research that, to this moment, has not involved any studies with natural planktonic bacteria, although immunofluorescence combined with flow cytometry was recently used to assess selective removal of natural bacterial strains by protistan grazers (Frette and del Giorgio, unpublished). 
Fluorescent in situ hybridization (FISH) has also the potential for being very useful in the near future. This technique relies upon the detection of specific sequences in the DNA or RNA of the intact target organisms, fluorescently labeled oligonucleotide probes (Amann et al., 1995). Fixation permeates walls and membranes and allows entrance of the probes in the cells, and incubation at a given temperature with added denaturing agents allows hybridization of probe and cellular material (Amann et al., 1990). rRNA oligonucleotide probes are ideal because the target sequence exists in thousands of copies (at least in growing bacteria). The oligonucleotide sequences are conjugated with a fluorescent compound, usually yellow-green stains like DTAF, FITC, or orange/red stains like $\mathrm{Cy} 3$ and Cy5. Most of the FISH work on natural assemblages to date has been performed using samples hybridized on filters and inspected using epifluorescence microscopy (Glöckner et al., 1999). Flow cytometry could potentially be used to detect hybridized cells, and has been used with cultured cells (Davey and Kell, 1996; Lange et al., 1997), but little work has been done with natural bacteria, mostly due to current technical limitations (e.g. Collier and Campbell, 1999).

The main technical problem is that natural bacteria are smaller and often less active than the cultured counterparts, and the ribosomal content in the target cells is often insufficient to produce enough probe-conferred fluorescence to be detected (Amann et al., 1990; Simon et al., 1995). Other technical problems include nonspecific binding of the probes (Wallner et al., 1993), interference of the counterstains (Wallner et al., 1995), loss of autofluorescence due to the permeabilization steps (Simon et al., 1995), or the length of time between dye excitation and emission. The passage of the cells through the illuminated zone typically lasts between 10-100 $\mu$ s. If the dyes are not emitting in this time frame, fluorescence will not be collected by the detectors. Only in wastewater treatment plants have FISH and FC been combined to detect non-cultured indigenous bacteria using flow cytometry (Wallner et al., 1995). The techniques, however, are being continually improved (Fuchs et al., 1998; Worden et al., 2000) and it is likely that in a near future FISH using flow cytometry may be routinely performed on bacterioplankton, as it is on phytoplankton (Jonker et al., 2000).

\section{Sorting specific microorganisms}

The possibility of sorting populations or identifiable fractions of bacteria is a key aspect of flow cytometric analysis but has been little explored in the case of natural bacteria. Porter et al. (1993) performed cell sorting of bacterial cultures diluted into lake water and then labeled with antibodies, with good recovery of viable organisms. In further studies they were able to recover $E$. coli which had not been intentionally added to a sewage sample, although this time with less purity (Porter et al., 1995b). Nir et al. (1990) showed that it was possible to sort and recover B-galactosidaseproducing bacteria and that the sorted populations were viable, and Rivkin et al. (1986) and Li (1994) have shown that it is possible to sort out phytoplankton after ${ }^{14} \mathrm{C}$-incorporation to obtain estimates of group-specific primary production. The phytoplankton cells were, in this case, affected by the exposure to the laser and were no longer photosynthetically active (Rivkin et al., 1986). Wallner et al. (1997) showed that it was possible to sort magnetotactic bacteria, based on their scatter properties; large planktonic bacteria, based on their DNA fluorescence, and specific bacteria, thanks to the hybridization to a given fluorescent probe. The DNA of the sorted cells could be amplified even though the cells had been fixed with PFA and had been later sorted. Similarly, Moore et al. (1998) and Urbach and Chisholm (1998) performed DNA analyses and physiological tests of different cytometrically-sorted strains of Prochlorococcus. Servais et al. (1999) have successfully separated radiolabeled High and Low DNA bacterial populations from a natural mixed bacterial assemblage, and have shown that the cell sorting procedure did not affect the measurements. Bernard et al. (1998) sorted CTC positive bacteria and compared their phylogenetic composition to that of CTC negative cells. The use of flow cytometry to separate specific bacterial groups for later genetic analysis, as well as the detection of specific genes in bacteria by means of in situ PCR (Porter et al., 1995c; 1998) is an area that will see strong development in the coming years. Sorting techniques and the potential of flow sorting aquatic microorganisms is reviewed by Reckermann (2000).

\section{PROBING BACTERIA TO UNDERSTAND ECOSYSTEM DYNAMICS}

We have reviewed the ways in which bacterial abundance can be determined in plankton samples 
by means of flow cytometry. From bacterial abundance, the biomass of bacteria can be estimated with standard conversion factors or with the procedures explained above to estimate cell sizes. Flow cytometry has already greatly increased our understanding of the distribution of microorganisms and their dominant metabolism in the plankton (i.e. phototrophs vs. heterotrophs), and has led to improved estimates of the global plankton carbon structure (e.g. Buck et al., 1996).

But carbon fluxes can also be estimated with the help of the cytometers. Sherr et al. (1999) have shown that a combination of i) the amount of CTCpositive bacteria, ii) an estimate of their average size (SSC) and iii) an estimation of the degree of respiratory activity of each cell (cell-specific CTC fluorescence) can be combined to predict with great accuracy the rates of bacterial production (measured as the uptake of tritiated aminoacids). This observation, when combined to the good correspondence encountered by Smith (1998) between the amount of CTC-positive bacteria and community respiration rates, allow for the first time the exploration of the linkage between cell-specific characteristics and their impact in whole ecosystem metabolism.

The flux of carbon from bacteria to their predators can also be estimated with the help of flow cytometry. Inspired by work done in the biomedical sciences (e.g. Bassøe et al., 1983), Monger and Landry (1992) used live-stained bacteria and dualbeam cytometry to monitor heterotrophic nanoflagellate grazing on bacteria. The bacteria were stained with FITC and were excited by the blue laser while the protozoans were stained with DAPI and excited by the UV laser. The method worked well for cultured bacteria and protozoans. VazquezDominguez et al. (1999) has recently adapted that method for use with field samples by labeling bacteria of a size similar to that of marine planktonic bacteria, reducing the nutrients that accompany the buffers used for the preparation of the FLBs (fluorescently labeled bacteria), and switching to longterm disappearance experiments which are more appropriate for open ocean environments. An image of these FLBs in a sample also containing large numbers of autofluorescent Synechococcus is plotted in Fig. 8 (lower panels). Flow cytometry has also been used to estimate the loss rates of bacteria and picoalgae to a variety of benthic animals: bivalves (Cucci et al., 1985; Shumway et al., 1985), sponges (Pile et al., 1996; Pile, 1997; Ribes et al., 1999a), ascidians (Ribes et al., 1998a) and gorgonian corals
(Ribes et al., 1998b). The methods presented in this review have proven fast and reliable for the study of the interaction between benthic organisms and their planktonic food (e.g. Ribes et al., 1999b). Work in progress suggests that we will soon be able to differentiate viral-infected from noninfected phytoplankton cells (Brussaard et al., 1999).

Most of the techniques reviewed in this paper are not older than 10 years. And their use has seen an exponential increase in the last two or three years. Recent work with flow cytometry has helped identify presumably active phytoplankton and bacteria in the deep ice above antarctic Lake Vostok (Karl et $a l ., 1999)$ with obvious implications for extraterrestrial studies. Furthermore, new instruments to facilitate this work are being constantly marketed (e.g. laser-scanning cytometers, Reynolds and Fricker, 1999). We expect further development of new techniques increasing the potential of flow cytometry to answer essential questions about the structure and the functioning of microbial food webs in plankton ecosystems.

\section{ACKNOWLEDGEMENTS}

Our experience in flow cytometry has grown thanks to useful advice and comments by David Bird, Jaume Comas, Michel Denis, Gérald Gregori, Paco Jiménez, Bill Li, Ricard López-Amorós, Yves Prairie, Jaime Rodríguez, Glenn Tarran, Temi VivesRego and Mike Zubkov. JMG thanks for various help his colleagues Cesc Peters, Evaristo Vázquez and Carlos Pedrós in Barcelona. We thank Isabel Casamajor for help with the fixatives experiment and Xavi Cristina for access to unpublished manuscripts. Jaume Comas let us compare the coincidence levels in the Coulter XL and Carlos Pedrós shared the Atlantic data presented in Fig. 6. We thank S. Canut for long-lasting support and Franciscus Colijn and Marcus Reckermann for the opportunity to participate in the Büsum symposium. This work has been supported by grants MAS3-CT950016 (MEDEA) and MAS3-CT97-0154 (MIDAS).

\section{REFERENCES}

Allman, R., A.C. Hann, A.P. Phillips, K.L. Martin and D. Lloyd. 1990. Growth of Azotobacter vinelandii with correlation of Coulter cell size, flow cytometric parameters, and ultrastructure. Cytometry, 11: 822-831.

Allman, R., A.C. Hann, R. Manchee and D. Lloyd. - 1992. Characterization of bacteria by multiparameter flow cytometry. $J$. 
Appl. Bacteriol., 73: 438-444.

Allman, R., R. Manchee and D. Lloyd. - 1993. Flow cytometric analysis of heterogeneous bacterial populations. In: Lloyd, D. (ed.), Flow cytometry in Microbiology, pp. 27-47. SpringerVerlag, London.

Amann, R.I., B.J. Binder, R.J. Olson, S.W. Chisholm, R. Devereux, and D.A. Stahl. - 1990. Combination of 16S rRNA-targeted oligonucleotide probes with flow cytometry for analyzing mixed microbial populations. Appl. Environ. Microbiol., 56: 1919-1925.

Amann, R. I., W. Ludwig and K. -H. Schleifer. - 1995. Phylogenetic identification and in situ detection of individual microbial cells without cultivation. Microbiol. Rev, 59: 143-169.

Azam, F. and R.E. Hodson. 1977. - Size distribution and activity of marine microheterotrophs. Limnol. Oceanogr., 22: 492-501.

Azam, F. - 1998. Microbial control of oceanic carbon flux: The plot thickens. Science, 280: 694-696.

Bailey, J.E., J. Fazel-Madjelessi, D.N. McQuitty, L.Y. Lee, J.C. Allred and J.A. Oro. - 1977. Characterization of bacterial growth by means of flow microfluorometry. Science, 198: $1175-1176$.

Bassøe, C.-F., O.D. Laerum, J. Glette, G.Hopen, B. Haneberg and C.O. Solberg. - 1983. Simultaneous measurement of phagocytosis and phagosomal $\mathrm{pH}$ by flow cytometry: Role of polymorphonuclear neutrophilic leukocyte granules in phagosomal acidification. Cytometry, 4: 254-262

Beck, P. and R. Huber. - 1997. Detection of viability in cultures of hyperthermophiles. FEMS Microb. Lett., 147: 11-14.

Bernard, L., P. Lebaron, H. Schäfer and G. Muyzer. - 1998. Combination of cellular and molecular techniques with cell sorting for bacterial identificaton of active bacteria in marine waters. Abstracts Sixth European Marine Microbiology Symposium. Sitges., p. 42

Bernarder, R., T. Stokke and E. Boye. - 1998. Flow cytometry of bacterial cells: comparison between different flow cytometers and different DNA stains. Cytometry, 31: 29-36.

Binder, B.J., S.W. Chisholm, R.J. Olson, S.L. Frankel and A.Z. Worden. - 1996. Dynamics of pico-phytoplankton, ultra-phytoplankton, and bacteria in the Central Equatorial Pacific. DeepSea Res. II, 43: 907-931.

Blackburn, N., A. Hagström, J. Wikner, R. Cuadros-Hansson and P.K. Bjørnsen. - 1998. Rapid determination of bacterial abundance, biovolume, morphology, and growth by neural network-based image analysis. Appl. Environ. Microbiol., 64: 3246-3255.

Blanchot, J. and M. Rodier. - 1996. Picophytoplankton abundance and biomass in the western tropical Pacific Ocean during the 1992 El Niño year: results from flow cytometry. Deep-Sea Res., 43: 877-895.

Booth, B.C. - 1987. The use of autofluorescence for analysing oceanic phytoplankton communities. Bot. Mar., 30: 101-108.

Boye, E., H.B. Steen and K. Skarstad. - 1983. Flow cytometry of bacteria: a promising tool in experimental and clinical microbiology. J. Gen. Microbiol., 129: 973-980.

Brussaard, C.P.D., R. Thyrhaug, D. Marie and G. Bratbak. - 1999. Flow cytometric analyses of viral infection in two marine phytoplankton species, Micromonas pusilla (Prasinophyceae) and Phaeocystis pouchetii (Prymnesiophyceae). J. Phycol., 35: 941-948

Buck, K.R., F.P. Chavez and L. Campbell. - 1996. Basin-wide distributions of living carbon components and the inverted trophic pyramid of the central gyre of the North Atlantic Ocean, summer 1993. Aquat. microb. Ecol., 10: 283-298.

Bullock, G. R. - 1984. The current status of fixation for electron microscopy: a review. J. Microscopy, 133: 1-15.

Button D.K. and B.R. Robertson. - 1989. Kinetics of bacterial processes in natural aquatic systems based on biomass as determined by high-resolution flow cytometry [erratum in Cytometry 1990;11(3):451] Cytometry, 10: 558-563.

Button D.K. and B.R. Robertson. - 1993. Use of high-resolution flow cytometry to determine the activity and distribution of aquatic bacteria. In: Kemp, P.F., B.F. Sherr, E.B. Sherr and J.J. Cole, (eds.). Handbook of methods in aquatic microbial ecology. pp. 163-173, Lewis Pub., Boca Raton.

Button, D.K., B.R. Robertson and F. Jüttner. - 1996. Microflora of a subalpine lake: bacterial populations, size and DNA distributions, and their dependence on phosphate. FEMS Microb. Ecol., 21: 87-101.

Campbell, L. and D. Vaulot. - 1993. Photosynthetic picoplankton community structure in the subtropical North Pacific Ocean near Hawaii (station ALOHA). Deep-Sea Res., 40: 2043-2060.

Campbell, L., H.A. Nolla and D. Vaulot - 1994. The importance of Prochlorococcus to community structure in the central North Pacific Ocean. Limnol. Oceanogr., 39: 954-961.

Campbell, L., L. Hongbin, H.A. Nolla and D. Vaulot. - 1997. Annual variability of phytoplankton and bacteria in the subtropical North Pacific at station ALOHA during the 1991-1994 ENSO event. Deep-Sea Res., 44: 167-192.

Campbell, L., M.R. Landry, J. Constantinou, H.A. Nolla, S. L. Brown, H. Liu and D.A. Caron. - 1998. Response of microbial community structure to environmental forcing in the Arabian Sea. Deep-Sea Res. II., 45: 2301- 2325.

Cantineaux, B., P. Courtoy and P. Fondu. - 1993. Accurate flow cytometric measurement of bacteria concentrations. Pathobiology, 61: 95-97.

Catala, P., N. Parthuisot, L. Bernard, J. Baudart, K. Lemarchand and P. Lebaron. - 1999. Effectiveness of CSE to counterstain particles and dead bacterial cells with permeabilised membranes: application to viability assessment in waters. FEMS Microb. Letters, 178: 219-226

Cole, J.J., S. Findlay and M.L. Pace. - 1988. Bacterial production in fresh and saltwater ecosystems: a cross-system overview. Mar. Ecol. Prog. Ser., 43: 1- 10.

Coleman, A.W., M. J. Maguire and J.R. Coleman. - 1981. Mithramycin- and 4'-6-diamidino-2-phenylindole (DAPI)DNA staining for fluorescence microspectrophotometric measurements of DNA in nuclei, plastids, and virus particles. $J$. Histochem. Cytochem., 29: 959-968.

Collier, J.L. and L. Campbell. - 1999. Flow cytometry in molecular aquatic ecology. Hydrobiologia, 401: 33-53

Comas, J. and J. Vives-Rego. - 1997. Assessment of the effects of gramicidin, formaldehyde, and surfactants on Escherichia coli by flow cytometry using nucleic acid and membrane potential dyes. Cytometry, 29: 58-64.

Comas, J. and J. Vives-Rego. - 1998. Enumeration, viability and heterogeneity in Staphylococcus aureus cultures by flow cytometry. J. Microbiol. Methods., 32: 45-53.

Cook, K. L. and J. L. Garland. - 1997. The relationship between electron transport activity as measured by CTC reduction and $\mathrm{CO}$ production in mixed microbial communities. Microb. Ecol., 34: 237-247.

Corzo, A., F. Jiménez-Gómez, F.J.L. Gordillo, R. García-Ruiz and F.X. Niell. - 1999. Synechococcus and Prochlorococcus-like populations detected by flow cytometry in a eutrophic reservoir in summer. J. Plankton Res., 21: 1575-1581

Crissman, H.A., A.P. Stevenson, D.J. Orlicky and R.J. Kissane. 1978. Detailed studies on the application of three fluorescent antibiotics for DNA staining in flow cytometry. Stain Technol., 53: $321-330$

Cucci, T.L., S.E. Shumway, R.C. Newell, R. Selvin, R.R.L. Guillard and C.M. Yentsch. - 1985. Flow cytometry; a new method for characterization of differential ingestion, digestion and egestion by suspension feeders. Mar. Ecol. Prog. Ser., 24: 201204

Chatila, K., S. Demers, B. Mostajir, J.-P. Chanut and P. Montfort. 1999. An endogenous periodicity exhibited in the activity of a natural bacterioplankton community isolated in microcosms. Can. J. Microbiol., 45: 555-564

Chisholm, S.W., R.J. Olson, E.R. Zettler, R. Goericke, J. Waterbury and N. Welschmeyer. - 1988. A novel free-living prochlorophyte abundant in the oceanic euphotic zone. Nature, 334: 340-343

Cho, B.C. and F. Azam. - 1988. Major role of bacteria in biogeochemical fluxes in the ocean's interior. Nature, 332: 441-443.

Christensen, H., L. R. Bakken and R. A. Olsen. - 1993. Soil bacterial DNA and biovolume profiles measured by flow cytometry. FEMS Microb. Ecol., 102: 129-140.

Darzynkiewicz, Z. and H.A. Crissman, (eds.). - 1990. Flow Cytometry. Methods in Cell Biology, volume 33. Academic Press.

Davey, H.M. and D.B. Kell. - 1996. Flow cytometry and cell sorting of heterogeneous microbial populations: the importance of single-cell analyses. Microbiol. Rev., 60: 641- 696.

Davey, H.M. and D.B. Kell - 1997. Fluorescent brighteners; novel stains for the flow cytometric analysis of microorganisms. Cytometry, 28: 311-315.

Davey, H.M., C.L. Davey and D.B. Kell. - 1993. On the determination of the size of microbial cells using flow cytometry. In: Lloyd, D. (ed.), Flow cytometry in Microbiology, pp. 49-65. Springer-Verlag, London. 
Davey, H.M., D.H. Weichart, D.B. Kell and A.S. Kaprelyants. - 1999. Estimation of microbial viability using flow cytometry. Current Protocols in Cytometry, 11.3.1-11.3.20, J. Wiley and Sons.

Deere, D., J. Porter, C. Edwards and R. Pickup. - 1995. Evaluation of the suitability of bis-(1,3-dibutylbarbituric acid) trimethine oxonol, (diBA-C4(3)-), for the flow cytometric assessment of bacterial viability. FEMS Microb. Lett., 130: 165-170.

del Giorgio, P.A., D.F. Bird, Y.T. Prairie and D. Planas. - 1996. Flow cytometric determination of bacterial abundance in lake plankton with the green nucleid acid stain SYTO 13. Limnol. Oceanogr.,41: 783-789.

del Giorgio, P.A., J.J. Cole and A. Cimbleris. - 1997a. Respiration rates in bacteria exceed phytoplankton production in unproductive aquatic systems. Nature, 385: 148-151.

del Giorgio, P.A., Y.T. Prairie and D.F. Bird. - 1997b. Coupling between rates of bacterial production and the abundance of metabolically active bacteria in lakes, enumerated using CTC reduction and flow cytometry. Microb. Ecol., 34: 144-154.

del Giorgio, P.A., D.F. Bird, R. Maranger and Y.T. Prairie. (in press). - Use of the exclusion nucleic-acid stain TOPRO-1 to assess cell stress or damage in natural bacterioplankton assemblages. Aquat. microb. Ecol.

DeLeo, P.C. and P. Baveye. - 1996. Enumeration and biomass estimation of bacteria in aqauifer microcosm studies by flow cytometry. Appl. Environ. Microbiol., 64: 3900-3909.

Depierreux, C., M.T. Le Bris, M.F. Michel, B. Valeur, M. Monsigny and F. Delmotte. - 1990. Benzoxazinone-kanamycin derivative: a new fluorescent probe for flow cytometry analysis of bacteria (Agrobacterium tumefaciens). FEMS Microb. Lett., 67: $237-244$

Diaper, J. P. and C. Edwards. - 1994a. Flow cytometric detection of viable bacteria in compost. FEMS Microb. Ecol., 14: 213-220.

Diaper, J.P. and C. Edwards. - 1994b. The use of fluorogenic esters to detect viable bacteria by flow cytometry. J. Appl. Bacteriol., 7: 221-228.

Diaper, J.P., K. Tither and C. Edwards. - 1992. Rapid assessment of bacterial viability by flow cytometry. Appl. Microbiol. Biotechnol., 38: 268-272.

Donnelly, C.W. and G.J. Baigent. - 1986. Method for flow cytometric detection of Listeria monocytogenes in milk. Appl. Environ. Microbiol., 52: 689-695.

Dorsey, J., C.M. Yentsch, S. Mayo and T.L. Cucci. - 1989. Rapid analytical technique for the assessment of cell metabolic activity in marine microalgae. Cytometry, 10: 622-628

Dubelaar, G.B.C., J.W.M. Visser and M. Donze. - 1987. Anomalous behaviour of forward and perpendicular light scattering of a cyanobacterium owing to intracellular gas vacuoles. Cytometry, 8: 405-412.

Ducklow, H.W. and C.A. Carlson. - 1992. Oceanic bacterial production. Adv. Microb. Ecol., 12: 113-181

Ducklow, H.W., D.L. Kirchman, H.L. Quinby, C.A. Carlson and H.G. Dam. - 1993. Stocks and dynamics of bacterioplankton carbon during the spring bloom in the eastern North Atlantic Ocean. Deep-Sea Res. II, 40: 245-263.

Dusenberry, J.A. and S.L.Frankel. - 1994. Increasing the sensitivity of a FACScan flow cytometer to study oceanic picoplankton. Limnol. Oceanogr., 39: 206-209.

Edwards, C. - 1996. Assessment of viability of bacteria by flow cytometry. In: M. Al-Rubeai and A. N. Emery (eds.). Flow cytometry applications in cell culture. pp. 291-310, Marcel Dekker, New York.

Fouchet, P., C. Jayat, Y. Héchard, M.-H. Ratinaud and G. Frelat. 1993. Recent advances of flow cytometry in fundamental and applied microbiology. Biol. Cell., 78: 95-109.

Fuchs, B. M., G. Wallner, W. Beisker, I. Schwippl, W. Ludwig and R. Amann. - 1998. Flow cytometric analysis of the in situ accessibility of Escherichia coli 16rRNA for fluorescently labeled oligonucleotide probes. Appl. Environ. Microbiol., 64: 4973-4982.

Fuhrman, J.A., T.D. Sleeter, C.A. Carlson and L.M. Proctor. 1989. Dominance of bacterial biomass in the Sargasso Sea and its ecological implications. Mar. Ecol. Prog. Ser. 57: 207-217.

Gasol, J.M. and X.A.G. Morán. - 1999. Effects of filtration on bacterial activity and picoplankton community structure as assessed by flow cytometry. Aquat. microb. Ecol., 16: 251-264.

Gasol, J.M., P.A. del Giorgio, R. Massana and C.M. Duarte. - 1995. Active versus inactive bacteria: size-dependence in a coasta marine plankton community. Mar. Ecol. Prog. Ser., 128: 91-97.
Gasol, J.M., P.A. del Giorgio and C.M. Duarte. - 1997. Biomass distribution of marine planktonic communities. Limnol. Oceanogr., 42: 1353-1363.

Gasol, J.M., U.L. Zweifel, F. Peters, J.A. Fuhrman and A. Hagström. - 1999. Significance of size and nucleic acid content heterogeneity as measured by flow cytometry in natural planktonic bacteria . Appl. Environ. Microbiol., 65: 4475-4483.

Gin, K.Y.H., S.W. Chisholm and R.J. Olson. - 1999. Seasonal and depth variation in microbial size spectra at the Bermuda Atlantic time series station. Deep-Sea Res. I, 46: 1221-1245.

Glöckner, F.O., B.M. Fuchs and R. Amann. - 1999. Bacterioplankton compositions in lakes and oceans: a first comparison based on fluorescence in situ hybridization. Appl. Environ. Microbiol., 65: 3721-3726.

Guindulain, T., J. Comas and J. Vives-Rego. - 1997. Use of nucleic acid dyes SYTO-13, TOTO-1, and YOYO-1 in the study of Escherichia coli and marine prokaryotic populations by flow cytometry. Appl. Environ. Microbiol., 63: 4608-4611.

Hall, J.A. - 1991. Long-term preservation of picophytoplankton for counting by fluorescence microscopy. Br. Phycol. J., 26: 169-174.

Haugland, R.P. - 1994. Spectra of fluorescent dyes used in flow cytometry. Meth. Cell Biol., 42: 641-663.

Haugland, R.P. - 1999. Handbook of fluorescent probes and research chemicals. Seventh Ed. Molecular Probes Inc.

Heldal, M., S. Norland, G. Bratbak and B. Riemann. - 1994. Determination of bacterial cell number and cell volume by means of flow cytometry, transmission electron microscopy, and epifluorescence microscopy. J. Microbiol. Methods, 20: 255-263.

Hess W.R., F. Partensky, G.W.M. van der Staay, J. Garcia-Fernandez, T. Boerner and D. Vaulot. - 1996. Coexistence of phycoerythrin and a chlorophyll a/b in a marine prokaryote. Proc. Natl. Acad. Sci. USA, 93: 11126-11130.

Hutter, K.-J. and H.E. Eipel. - 1978. Flow cytometric determinations of cellular substances in algae, bacteria, moulds and yeasts. Ant. van Leeuwenhoek, 44: 269-282.

Ibrahim, P., A.S. Whiteley and M.R. Barer. - 1997. SYTO 16 labelling and flow cytometry of Mycobacterium avium. Lett. Appl. Microbiol., 25: 437-441.

Ingram, M.L., T.J. Cleary, B.J. Price, R.L. Price and A. Castro. 1982. Rapid detection of Legionella pneumophila by flow cytometry. Cytometry, 3: 134-137.

Jacobsen, C.N., J. Rasmussen and M. Jakobsen. - 1997. Viability staining and flow cytometric detection of Listeria monocytogenes. J. Microbiol. Methods., 28: 35-43.

Jacquet, S., J.-F. Lennon and D. Vaulot. - 1998a. Application of a compact automatic sea water sampler to high frequency picoplankton studies. Aquat. microb. Ecol., 14: 309-314.

Jacquet, S., J.-F. Lennon, D. Marie and D. Vaulot. - 1998b. Picoplankton population dynamics in coastal waters of the northwestern Mediterranean Sea. Limnol. Oceanogr., 43: 1916-1931.

Jellett, J.F., W.K.W. Li, P.M. Dickie, A. Boraie and P.E. Kepkay.1996. Metabolic activity of bacterioplankton communities assessed by flow cytometry and single carbon substrate utilization. Mar. Ecol. Prog. Ser., 136: 213-225.

Jepras, R.I., J. Carter, S.C. Pearson, F.E. Paul and M.J. Wilkinson. - 1995. Development of a robust flow cytometric assay for determining numbers of viable bacteria. Appl. Environ. Microbiol., 61: 2696-2701.

Jernaes, M.W. and H.B. Steen. - 1994. Staining of Escherichia coli for flow cytometry: Influx and efflux of ethidium bromide. Cytometry, 17: 302-309.

Jochem, F.J. - 2000. Probing the physiological state of phytoplankton at the single cell level. Sci. Mar., 64(2): 183-195.

Jonker, R., R. Groben, G. Tarran, L. Medlin, M. Wilkins, L. Garcia, L. Zabala and L. Boddy. - 2000. Automated identification and characterization of microbial populations using flow cytometry: The AIMS Project. Sci. Mar., 64(2): 225-234.

Joux, F., P. Lebaron and M. Troussellier. - 1997. Succession of cellular states in a Salmonella typhimurium population during starvation in artificial seawater microcosms. FEMS Microb. Ecol., 22: 65-76.

Jürgens, K. and H. Güde. - 1994. The potential importance of grazing-resistant bacteria in planktonic systems. Mar. Ecol. Prog. Ser., 112: 169-188.

Kaprelyants, A.S. and D.B. Kell. - 1992. Rapid assessment of bacterial viability and vitality by rhodamine 123 and flow cytometry. J. Appl. Bacteriol., 72: 410-422.

Kaprelyants, A.S. and D.B. Kell. - 1993a. The use of 5-cyano-2,3- 
ditolyl tetrazolium chloride and flow cytometry for the visualisation of respiratory activity in individual cells of Micrococcus luteus. J. Microbiol. Methods, 17: 115-122.

Kaprelyants, A.S. and D.B. Kell. - 1993b. Dormancy in stationaryphase cultures of Micrococcus luteus: flow cytometric analysis of starvation and resuscitation. Appl. Environ. Microbiol., 59: 3187-3196.

Karl, D.M., D.F. Bird, K. Bjorkman, T. Houlihan, R. Shackelford and L. Tupas. - 1999. Microorganisms in the accreted ice of Lake Vostok, Antarctica. Science, 286: 2144-2147.

Kell D.B., H. M. Ryder, A.S. Kaprelyants and H.V. Westerhoff. 1991. Quantifying heterogeneity: flow cytometry of bacterial cultures. Ant. van Leeuwenhoek., 60: 145-158.

Kepner, R.L. and J.R. Pratt. - 1994. Use of fluorochromes for direct enumeration of total bacteria in environmental samples: Past and present. Microbiol. Rev., 58: 603-615.

Kim, Y., J.H. Jett, E.J. Larson, J.R. Penttila, B.L. Marrone and R. A. Keller. - 1999. Bacterial fingerprinting by flow cytometry: Bacterial species discrimination. Cytometry, 36: 324-332.

Kirchman, D.L. - 1993. Leucine incorporation as a measure of biomass production by heterotrophic bacteria. In: Kemp, P.F., B.F. Sherr, E.B.Sherr and J.J. Cole. (eds.) Handbook of methods in aquatic microbial ecology. pp. 509-512. Lewis Pub., Boca Raton.

Koch, A.L., B.R. Robertson and D.K. Button. - 1996. Deduction of the cell volume and mass from forward scatter intensity of bacteria analyzed by flow cytometry. J. Microbiol. Methods., 27: 49-61.

Landry, M.L., J. Kirshten and J. Constantinou. - 1996. Abundance and distributions of picoplankton populations in the central equatorial Pacific from $12^{\circ} \mathrm{N}$ to $12^{\circ} \mathrm{S}, 140^{\circ} \mathrm{W}$. Deep-Sea Res., 43: 871-890

Lange, J.L., P.S. Thorne and N. Lynch. - 1997. Application of flo cytometry and fluorescent in situ hybridization for assessment of exposures to airborne bacteria. Appl. Environ. Microbiol., 63: 1557-1563.

Latimer, P. - 1982. Light Scattering and absorption as methods of studying cell population parameters. Ann. Rev. Biophys. Bioeng., 11: 129-150.

Lebaron, P. and F. Joux. - 1994. Flow cytometric analysis of the cellular DNA content of Salmonella typhimurium and Alteromonas haloplanktis during starvation and recovery in seawater. Appl. Environ. Microbiol., 60: 4345-4350.

Lebaron, P., N. Parthuisot and P. Catala. - 1998. Comparison of blue nucleic acid dyes for flow cytometric enumeration of bacteria in aquatic systems. Appl. Environ. Microbiol., 64: 1725-1730.

Lebaron, P., P. Servais, M. Troussellier, C. Courties, J. Vives-Rego, G. Muyzer, L. Bernard, T. Guindulain, H. Schäfer and E. Stackebrandt. - 1999. Changes in bacterial community structure in seawater mesocosms differing in their nutrient status. Aquat. microb. Ecol., 19: 255-267.

Lee, S. and J.A. Fuhrman. - 1987. Relationships between biovolume and biomass of naturally derived marine bacterioplankton. Appl. Environ. Microbiol., 53: 1298-1303.

Leyval, D., F. Debay, J.-M. Engasser and J.-L. Goergen. - 1997. Flow cytometry for the intracellular $\mathrm{pH}$ measurement of glutamate producing Corynebacterium glutamicum. J. Microbiol. Methods., 29: 121-127.

Li, W.K.W. - 1994. Primary production of prochlorophytes, cyanobacteria, and eucaryotic ultraphytoplankton: Measurements from flow cytometric sorting. Limnol. Oceanogr., 39: 169-175.

Li, W.K.W. - 1997. Cytometric diversity in marine ultraphytoplankton. Limnol. Oceanogr., 42: 874-880.

Li, W.K.W., P.M. Dickie, B.D. Irwin and A.M. Wood. - 1992. Biomass of bacteria, cyanobacteria, prochlorophytes and photosynthetic eukaryotes in the Sargasso Sea. Deep-Sea Res., 39: 501-519.

Li, W.K.W., J.F. Jellett and P.M. Dickie, P M. - 1995. DNA distributions in planktonic bacteria stained with TOTO or TO-PRO. Limnol. Oceanogr., 40: 1485-1495.

Lloyd, D. - 1993 (ed). Flow Cytometry in Microbiology. Springer, London.

Long, R.A. and F. Azam. - 1996. Abundant protein-containing particles in the sea. Aquat. microb. Ecol., 10: 213-221.

López-Amorós, R. J. Comas, C. Carulla and J. Vives-Rego. - 1994. Variations in flow cytometric forward scatter signals and cell size in batch cultures of Escherichia coli. FEMS Microbiol. Letters., 117: 225-230.
López-Amorós, R., D.J. Mason and D. Lloyd. - 1995a. Use of two oxonols and a fluorescent tetrazolium dye to monitor starvation of Escherichia coli in seawater by flow cytometry. J. Microbiol. Methods., 22: 165-176.

López-Amorós, R., J. Comas and J. Vives-Rego. - 1995b. Flow cytometric assessment of Escherichia coli and Salmonella typhimurium starvation-survival in seawater using Rhodamine 123, Propidium iodide, and oxonol. Appl. Environ. Microbiol., 61: 2521-2526.

López-Amorós, R., S. Castel, J. Comas-Riu and J. Vives-Rego. 1997. Assessment of E. coli and Salmonella viability and starvation by confocal laser microscopy and flow cytometry using Rhodamine 123, DiBAC4(3), Propidium Iodide, and CTC. Cytometry, 29: 298-305.

López-Amorós, R., J. Comas, M.T. García and J. Vives-Rego. 1998. Use of the 5-cyano-2,3-ditolyl tetrazolium chloride reduction test to assess respiring marine bacteria and grazing effects by flow cytometry during linear alkylbenzene sulfonate degradation. FEMS Microb. Ecol., 27: 33-42.

Lloyd, D. (ed.). - 1993. Flow cytometry in Microbiology. SpringerVerlag, London.

Marie, D., R. Casotti, N. Simon, F. Partensky and D. Vaulot. 1993. Flow cytometric measurements of Prochlorococcus and bacteria cell concentration, cell scatter, pigment fluorescence and cell cycle. Prochlorophyte Workshop pp. 40-44.

Marie, D., F. Partensky and D. Vaulot. - 1996. Application of the novel DNA dyes YOYO-1, YOPRO-1 and Picogreen for flow cytometric analysis of marine prokaryotes. Appl. Environ. Microbiol., 62: 1649-1655.

Marie, D., F. Partensky, S. Jacquet and D. Vaulot. - 1997. Enumeration and cell cycle analysis of natural populations of marine picoplankton by flow cytometry using the nucleic acid stain SYBR Green I. Appl. Environ. Microbiol., 63: 186-193.

Marie, D. C.P.D. Brussard, R. Thyrhaug, G. Bratbak and D. Vaulot. - 1999. Enumeration of marine viruses in culture and natural samples by flow cytometry. Appl. Environ. Microbiol., 65: 45-52.

Mason, D.J., R. López-Amorós, R. Allman, J.M. Stark and D. Lloyd. - 1995. The ability of membrane potential dyes and calcafluor white to distinguish between viable and non-viable bacteria. J. Appl. Bacteriol., 78: 309-315.

Massana, R., J.M. Gasol, P.K. Bjørnsen, N. Blackburn, А Hagström, S. Hietanen, B.H. Hygum , J. Kuparinen and C. Pedrós-Alió. - 1997. Measurement of bacterial size via analysis of epifluorescence preparations: description of an inexpensive system and solutions to some of the most common problems. Sci. Mar., 61: 397-407.

McClelland, R.G. and A.C. Pinder. - 1994. Detection of low levels of specific Salmonella species by fluorescent antibodies and flow cytometry. J. Appl. Bacteriol., 77: 440-447.

McFeters, G.A., A. Singh, S. Byun, P.R. Callis and S. Williams. 1991. Acridine orange staining reaction as an index of physiological activity in Escherichia coli. J. Microbiol. Methods., 13: 87-97.

McFeters, G.A., F.P. Yu, B.H. Pyle and P.S. Stewart. - 1995. Physiological assessment of bacteria using fluorochromes. J. Microbiol. Methods., 21: 1-13.

Miao, F., P. Todd and D.S. Kompala. - 1993. A single cell assay for $B$-galactosidase in recombinant $E$. coli using flow cytometry. Biotechnol. Bioeng., 42: 708-715.

Miller, J.S. and J.M. Quarles. - 1990. Flow cytometric identification of microorganisms by dual staining with FITC and PI. Cytometry, 11: 667-675.

Monfort, P. and B. Baleux. - 1992. Comparison of flow cytometry and epifluorescence microscopy for counting bacteria in aquatic ecosystems. Cytometry, 13: 188-192.

Monfort, P. and B. Baleux. - 1994. Effects of environmental factors in the St. Lawrence Estuary (Quebec, Canada) on experimental survival of Salmonella salamae as determined by flow cytometry. Can. J. Microbiol., 40: 712-719.

Monfort, P. and B. Baleux. - 1996. Cell cycle characteristics and changes in membrane potential during growth of Escherichia coli as determined by a cyanine dye and flow cytometry. $J$. Microbiol. Meth., 25: 79-86.

Monger, B.C. and M.R. Landry. - 1992. Size-selective grazing by heterotrophic nanoflagellates: an analysis using live stained bacteria and dual beam flow cytometry. Arch. Hydrobiol. Beih., 37: $173-185$. 
Monger, B.C. and M.R. Landry. - 1993. Flow cytometric analysis of marine bacteria with Hoechst 33342. Mar. Ecol. Prog. Ser. 59: $905-911$

Moore, L.R., G. Rocap and S.W. Chisholm. - 1998. Physiology and molecular phylogeny of coexisting Prochlorococcus ecotypes. Nature, 393: 464-467.

Mostajir, B., S. Demers, S. de Mora, C. Belzile, J.-P. Chanut, M. Gosselin, S. Roy, P. Zulema-Villegas, J. Fauchot, J. Bouchard, D. Bird, P. Montfort and M. Levasseur. - 1999. Experimental test of the effect of ultraviolet-B radiation in a planktonic community. Limnol. Oceanogr., 44: 586-596.

Nebe-Von Caron, G. and R.A. Badley. - 1995. Viability assessment of bacteria in mixed populations using flow cytometry. $J$ Microsc., 179: 55-66.

Nebe-von Caron, G., P. Stephens and R.A. Badley. - 1998. Assessment of bacterial viability status by flow cytometry and single cell sorting. J. Appl. Microbiol., 84: 988-998.

Nir, R., Y. Yisraeli, R. Lamed and E. Sahar. - 1990. Flow cytometry sorting of viable bacteria and yeasts according to ß-galactosidase activity. Appl. Environ. Microbiol., 56: 3861-3866.

Nishimura, M., K. Kogure, K. Kita-Tsukamoto and K. Ohwada. 1995. Detection and direct count of specific bacteria in natural seawater using $16 \mathrm{~S}$ rRNA oligonucleotide probe. Bull. Jap. Soc. Mic. Ecol., 10: 109-113.

Novo, D., N.G. Perlmutter, R.H. Hunt and H.M. Shapiro. - 1999. Accurate flow cytometric membrane potential measurement in bacteria using diethyloxacarbocyanine and a radiometric technique. Cytometry, 35: 55-63.

Nybroe, O. - 1995. Assessment of metabolic activity of single bacterial cells - new developments in microcolony and dehydrogenase assays. FEMS Microbiol. Ecol., 17: 77-84.

Olson, R.J., S.W. Chisholm, E.R. Zettler, M.A. Altabet and J.A. Dusenberry. - 1990. Spatial and temporal distributions of prochlorophyte picoplankton in the North Atlantic Ocean. Deep-Sea Res., 37:1033-1051.

Ormerod, M.G. 1994. Flow Cytometry: A practical approach. IRL Press, Oxford.

Paau, A.S., J.R. Cowles and J. Oro. - 1977. Flow-microfluorometric analysis of Escherichia coli, Rhizobium meliloti, and Rhizobium japonicum at different stages of the growth cycle. Can. J. Microbiol., 23: 1165-1169.

Paau, A.S., J.R. Cowles, J. Oro, A. Bartel and E. Hungerford. 1979. Separation of algal mixtures and bacterial mixtures with flow-microflorometer using chlorophyll and ethidium bromide fluorescence. Arch. Microbiol., 120: 217-273.

Partensky, F., J. Blanchot, F. Lantoine, J. Neveux and D. Marie. 1996. Vertical structure of picophytoplankton at different trophic sites of the tropical northeastern Atlantic Ocean. DeepSea Res., 43: 1191-1213.

Peters, D.C. - 1979. A comparison of mercury arc lamp and laser illumination for flow cytometry. J. Histochem. Cytochem., 27 241-245.

Peters, F., C. Marrasé, J.M. Gasol, M.M. Sala and L. Arin. - 1998. Food-web mediated effects of turbulence on bacterial production and growth. Mar. Ecol. Prog. Ser., 172: 293-303.

Petit, J.-M., M. Denis-Gay, M.-H. Ratinaud. - 1993. Assessment of fluorochromes for cellular structure and function studies by flow cytometry. Biol. Cell., 78: 1-13.

Philips, A.P. and K.L. Martin. - 1983. Immunofluorescence analysis of Bacillus spores and vegetative cells by flow cytometry. Cytometry, 4: 123-131.

Pile, A.J. - 1997. Finding Reswig's missing carbon: Quantification of sponge feeding using dual beam flow cytometry. Proc. $8 \mathrm{th}$ Coral Reef Symp., 2: 1403-1410.

Pile, A.J., M.R. Patterson and J.D. Witman. - 1996. In situ grazing on plankton $<10 \mu \mathrm{m}$ by the boreal sponge Mycale lingua. Mar. Ecol. Prog. Ser., 141: 95-102.

Pinder, A.C., P.W. Purdy, S.A.G. Poulter and D.C. Clark. - 1990. Validation of flow cytometry for rapid enumeration of bacterial concentrations in pure cultures. J. Appl. Bacteriol., 69: 92-100.

Porter, J., C. Edwards, J.A.W. Morgan, R.W. Pickup. - 1993. Rapid, automated separation of specific bacteria from lake water and sewage by flow cytometry and cell sorting. Appl. Environ. Microbiol., 59: 3327-3333.

Porter, J., J. Diaper, C. Edwards and R. Pickup. - 1995a. Direct measurements of natural planktonic bacterial community viability by flow cytometry. Appl. Environ. Microbiol., 61: 2783-2786.

Porter, J., J. Robinson, R. Pickup and C. Edwards. - 1995b. Recov- ery of a bacterial population from sewage using immunofluorescent flow cytometry and cell sorting. FEMS Microb. Lett., 133: $195-199$

Porter, J., R. Pickup and C. Edwards. - 1995c. Flow cytometric detection of specific genes in genetically modified bacteria using in situ polymerase chain reaction. FEMS Microb. Lett., 134: 51-56.

Porter, J., D. Deere, R. Pickup and C. Edwards. - 1996. Fluorescent probes and flow cytometry: new insights into environmental bacteriology. Cytometry, 23: 91-96.

Porter, J., D. Deere, M. Hardman, C. Edwards and R. Pickup. 1997. Go with the flow - use of flow cytometry in environmental microbiology. FEMS Microb. Ecol., 24: 93-101.

Porter, J., J. Robinson, R. Pickup and C. Edwards. - 1998. An evaluation of lectin-mediated magnetic bead cell sorting for the targeted separation of enteric bacteria. J. Appl. Bacteriol., 84: 722-732.

Reckermann, M. - 2000. Flow sorting in aquatic ecology. Sci. Mar., 64(2): 235-246.

Reckermann, M. and M.J.W. Veldhuis - 1997. Trophic interactions between picophytoplankton and micro- and nanozooplankton in the western Arabian Sea during the NE monsoon 1993. Aquat. microb. Ecol., 12: 263 - 273.

Reynolds, D.T. and C.R. Fricker. - 1999. Application of laser scanning for the rapid and automated detection of bacteria in water samples. J. Appl. Microbiol., 86: 785-795.

Ribes, M., R. Coma and J.-M. Gili. - 1998a. Seasonal variation of in situ feeding rates by the temperate ascidian Halocynthia papillosa. Mar. Ecol. Prog. Ser., 175: 201-213.

Ribes, M., R. Coma and J.-M. Gili. - 1998b. Heterotrophic feeding by gorgonian corals with symbiotic zooxanthella. Limnol. Oceanogr., 43: 1170-1179.

Ribes, M., R. Coma and J.-M. Gili. - 1999a. Natural diet and grazing rate of the temperate sponge Dysidea avara (Demospongiae, Dendroceratida) throughout an annual cycle. Mar. Ecol. Prog. Ser., 176: 179-190.

Ribes, M., R. Coma and J.-M. Gili. - 1999b. Seasonal variation of particulate organic carbon, dissolved organic carbon and the contribution of microbial communities to the live particular carbon in a shallow near-bottom ecosystem at the Northwestern Mediterranean Sea. J. Plank. Res., 21: 1077-1100.

Rice, J., M.A. Sleigh, P.H. Burkill, G.A. Tarran, C.D. O'Connor and M. Zubkov. - 1997. Flow cytometric analysis of characteristics of hybridization of species-specific fluorescent oligonucleotide probes to rRNA of marine nanoflagellates. Appl. Environ. Microbiol., 63: 938-944.

Rivkin, R.B., D.A. Phinney and C.M. Yentsch. - 1986. Effects of flow cytometric analysis and cell sorting on photosynthetic carbon uptake by phytoplankton in cultures and from natural populations. Appl. Environ. Microbiol., 52: 935-938.

Robertson B.R. and D.K. Button. - 1989. Characterizing aquatic bacteria according to population, cell size and apparent DNA content by flow cytometry. Cytometry, 10: 70-76.

Robertson, B.R., D.K. Button and A.L. Koch. - 1998. Determination of the biomasses of small bacteria at low concentrations in a mixture of species with forward light scatter measurements by flow cytometry. Appl. Environ. Microbiol., 64: 3900-3909.

Roszak, D. B. and R. R. Colwell. - 1987. Survival strategies of bacteria in the natural environment. Microbiol. Rev., 51: 365-379.

Roth, B.L., M. Poot, S.T. Yue and P.J. Millard. - 1997. Bacterial viability and antibiotic susceptibility testing with SYTOX green nucleic acid stain. Appl. Environ. Microbiol., 63: 2421-2431.

Servais, P., C. Courties, P. Lebaron and M. Trousssellier. - 1999. Coupling bacterial activity measurements with cell sorting by flow cytometry. Microb. Ecol., 38:180-189.

Shalapyonok, A., R.J. Olson and L.S. Shalapyonok. - 1998. Ultradian growth in Prochlorococcus spp. Appl. Environ. Microbiol., 64: 1066-1069.

Shapiro, H.M. - 1995. Practical flow cytometry. Third Edition. Wiley-Liss.

Sherr, B.F., P. A. del Giorgio and E. B. Sherr. - 1999. Estimating the abundance and single-cell characteristics of respiring bacteria via the redox dye, CTC. Aquat. microb. Ecol., 18: 117-131.

Shumway, S.E., T.L. Cucci, R.C. Newell and C.M. Yentsch. 1985. Particle selection, ingestion and absorption in filter-feeding bivalves. J. Exp. Mar. Biol. Ecol, 91: 77-92.

Sieracki, M.E. and C.L. Viles. - 1992. Distributions and fluorochrome-staining properties of sub-micrometer particles and bacteria in the North Atlantic. Deep-Sea Res., 39: 1919-1929. 
Sieracki, M.E., E.M. Haugen and T.L. Cucci. - 1995. Overestimation of heterotrophic bacteria in the Sargasso Sea: direct evidence by flow and imaging cytometry. Deep-Sea Res., 42: 1399-1409.

Sieracki, M.E., T.L. Cucci and J. Nicinski. - 1999. Flow cytometric analysis of CTC-activity of marine bacterioplankton in dilution cultures. Appl. Environ. Microbiol., 65: 2409-2417.

Simon, M., B.C. Cho and F. Azam. - 1992. Significance of bacterial biomass in lakes and the ocean: comparison to phytoplankton biomass and biogeochemical implications. Mar. Ecol. Prog. Ser., 86: 103-110.

Simon, N., N. LeBot, D. Marie, F. Partensky and D. Vaulot. - 1995. Fluorescent in situ hybridization with rRNA-targeted oligonucleotide probes to identify small phytoplankton by flow cytometry. Appl. Environ. Microbiol., 61: 2506-2513.

Smith, E.M. - 1998. Coherence of microbial respiration rate and cell-specific bacterial activity in a coastal planktonic community. Aquat. microb. Ecol., 16: 27-35.

Srienc, F., B. Arnold and J.E. Bailey. - 1984. Characterization of intracellular accumulation of Poly-ß-hydroxybutyrate (PHB) in individual cells of Alcaligenes eutrophus $\mathrm{H} 16$ by flow cytometry. Biotechnol. Bioeng., 26: 982-987.

Steen, H.B. - 1990. Flow cytometric studies of microorganisms. In: Melamed, M.R., T. Lindmo and M.L. Mendelsohn (eds.). Flow cytometry and sorting. 2nd. pp. 605-622. Ed. Wiley-Liss Inc., NY

Steen, H.B. and T. Lindmo. - 1979. Flow cytometry: A high-resolution instrument for everyone. Science, 204: 403-404.

Steen, H.B. and E. Boye. - 1981. Escherichia coli growth studied by dual-parameter flow cytophotometry. J. Bacteriol., 145: 1091-1094.

Steen, H.B., E. Boye, K. Skarstad, B. Bloom, T. Godal and S. Mustafa. - 1982. Applications of flow cytometry on bacteria: cell cycle kinetics, drug effects, and quantification of antibody binding. Cytometry, 2: 249-257.

Steen, H.B., K. Skarstad and E. Boye. - 1986. Flow cytometry of bacteria: Cell cycle kinetics and effects of antibiotics. Ann. N.Y. Acad. Sci., 468: 357-370.

Steen, H.B., K. Skarstad and E. Boye. - 1990. DNA measurements of bacteria. Meth. Cell Biol., 33: 519-526.

Steen, H.B., M.W. Jernaes, K. Skarstad and E. Boye. - 1994. Staining and measurement of DNA in bacteria. Meth. Cell Biol., 42: 477-487.

Thom, S M, Horobin, R W, Seidler, E, Barer, M R. - 1993. Factors affecting the selection and use of tetrazolium salts as cytochemical indicators of microbial viability and activity. J. Appl. Bacteriol. 74: 433-443

Thorsen, B.K., Ø. Enger, S. Norland and K.A. Hoff. - 1992. Longterm starvation survival of Yersinia ruckeri at different salinites studied by microscopical and flow cytometric methods. Appl. Environ. Microbiol., 58: 1624-1628.

Troussellier, M., C. Courties and A. Vaquer. - 1993. Recent applications of flow cytometry in aquatic microbial ecology. Biol. Cell., 78: 111-121.

Troussellier, M., C. Courties and S. Zettelmaier. - 1995. Flow cytometric analysis of coastal lagoon bacterioplankton and picophytoplankton : Fixation and storage effects. Est. Coast. Shelf Sci., 40: 621-633.

Troussellier M., C. Courties, P. Lebaron and P. Servais. - 1999. Flow cytometric discrimination of bacterial populations in seawater based on SYTO 13 staining of nucleic acids. FEMS Microbiol. Ecol., 29: 319-330.

Tyndall, R.L., R.E. Hand, R.C. Mann, C. Evans and R. Jernigan. 1985. Application of flow cytometry to detection and characterization of Legionella spp. Appl. Environ. Microbiol., 49: 852-857.

Ullrich, S., B. Karrasch, H.-G. Hoppe, K. Jeskulke and M. Mehrens. - 1996. Toxic effects on bacterial metabolism of the redox dye 5-cyano-2,3-ditolyl tetrazolium chloride. Appl. Environ. Microbiol., 62:4587-4593.

Urbach, E. and S.W. Chisholm. - 1998. Genetic diversity in Prochlorococcus populations flow cytometrically sorted from the Sargasso Sea and Gulf Stream. Limnol. Oceanogr., 43: 1615-1630.

van Dilla, M.A., R.G. Langlois, D. Pinkel, D. Yajko and W.K. Hadley. - 1983. Bacterial characterization by flow cytometer. Science, 220: 620-622.
Vaulot, D., C. Courties and F. Partensky. - 1989. A simple method to preserve oceanic phytoplankton for flow cytometric analyses. Cytometry, 10: 629-636.

Vaulot, D., D. Marie, R.J. Olson and S.W. Chisholm. - 1995. Growth of Prochlorococcus, a photosynthetic prokaryote, in the Equatorial Pacific Ocean. Science, 268: 1480-1482.

Vazquez-Dominguez, E., F. Peters, J.M. Gasol and D. Vaqué. - 1999. Measuring the grazing losses of picoplankton: Methodological improvements to the use of fluorescently labeled tracers combined to flow cytometry. Aquat. m-icrob. Ecol., 20: 119-128.

Veldhuis M.J.W., T.L. Cucci and M.E. Sieracki. - 1997. Cellular DNA content of marine phytoplankton using two new fluorochromes: taxonomic and ecological implications. J. Phycol., 33: 527-541.

Veldhuis M.J.W. and G.W. Kraay. - 2000. Application of flow cytometry in marine phytoplankton research: current applications and future perspectives. Sci. Mar., 64(2): 121-134.

Vesey, G., J. Narai, N. Ashbolt, K. Williams and D. Veal. - 1994. Detection of specific microorganisms in environmental samples using flow cytometry. Meth. Cell Biol., 42: 489-522.

Vives-Rego, J., R. López-Amorós and J. Comas. - 1994. Flow cytometric narrow-angle light scatter and cell size during starvation of Escherichia coli in artificial sea water. Letters Appl. Microbiol., 19: 374-376.

Vives-Rego, J., T. Guindulain, E. Vazquez-Dominguez, J.M. Gasol, R. López-Amorós, D. Vaqué and J. Comas. - 1999. Assessment of the effects of nutrients and pollutants on coastal bacterioplankton by flow cytometry and SYTO-13 staining. Microbios, 98: 71-85.

Wallberg, M., P. Gaustad and H.B.Steen. - 1998. Rapid preparation procedure for staining of exponentially growing $P$. vulgaris cells with ethidium bromide: a flow cytometry-based study of probe uptake under various conditions. J. Microbiol. Meth., 34: 49-58.

Wallner, G., R. Amann and W. Beisker. - 1993. Optimizing fluorescent in situ hybridization with rRNA-targeted oligonucleotide probes for flow cytometric identification of microorganisms. Cytometry, 14: 136-143.

Wallner, G., R. Erhart and R. Amann. - 1995. Flow cytometric analysis of activated sludge with rRNA-targeted probes. Appl. Environ. Microbiol., 61: 1859-1866.

Wallner, G., B. Fuchs, S. Spring, W. Beisker and R. Amann. 1997. Flow sorting of microorganisms for molecular analysis. Appl. Environ. Microbiol., 63: 4223-4231.

Williams, S.C., Y. Hong, D.C.A. Danavall, M.H. Howard-Jones, D. Gibson, M.E. Frischer and P.G. Verity. - 1998. Distinguishing between living and nonliving bacteria: Evaluation of the vital stain propidium iodide and its combined use with molecular probes in aquatic samples. J. Microbiol. Meth., 32: 225-236.

Wittrup, K.D., M.B. Mann, D.M. Fenton, L.B. Tsai and J.E. Bailey. 1988. Single cell light scatter as a probe of refractile body formation in recombinant Escherichia coli. Bio/Technol., 6: 423-426.

Worden, A.Z., S.W. Chisholm and B.J. Binder. - 2000. In situ hybridization of Prochlorococcus and Synechococcus (marine cyanobacteria) spp. with rRNA-targeted peptide nucleic acid probes. Appl. Environ. Microbiol., 66: 284-289.

Yamaguchi, N. and M. Nasu. - 1997. Flow cytometric analysis of bacterial respiratory and enzimatic activity in the natural aquatic environment. J. Appl. Microbiol., 83: 43-52.

Yentsch, C.M., P.K. Horan, K. Muirhead, Q. Dortch, E. Haugen, L. Legendre, L. S. Murphy, M.J. Perry, D.A. Phinney, S.A. Pomponi, R.W. Spinrad, M. Wood, C.S. Yentsch and B. J. Zahuranec. - 1983. Flow cytometry and cell sorting: A technique for analysis and sorting of aquatic particles. Limnol. Oceanogr., 28: $1275-1280$.

Zubkov, M.V., B.M. Fuchs, H. Eilers, P.H. Burkill and R. Amann. - 1999. Determination of total protein content of bacterial cells by SYPRO staining and flow cytometry. Appl. Environ. Microbiol., 65: 3251-3257.

Zubkov, M.V., M.A. Sleigh, G.A. Tarran, P.H. Burkill and R.J.G. Leakey. - 1998. Picoplankton community structure on an Atlantic transect from $50^{\circ} \mathrm{N}$ to $50^{\circ} \mathrm{S}$. Deep-Sea Res. I, 45: 13391355.

Zweifel, U.L. and Å. Hagström. - 1995. Total counts of marine bacteria include a large fraction of non-nucleoid-containing bacteria (ghosts). Appl. Environ. Microbiol., 61: 2180-2185. 